\author{
A POLL TAX BY ANY OTHER NAME: \\ THE POLITICAL ECONOMY OF DISENFRANCHISEMENT \\ Daniel B. Jones \\ Werner Troesken \\ Randall Walsh \\ Working Paper 18612 \\ http://www.nber.org/papers/w18612
}

\author{
NATIONAL BUREAU OF ECONOMIC RESEARCH \\ 1050 Massachusetts Avenue \\ Cambridge, MA 02138 \\ December 2012
}

We thank George Krause for helpful comments and suggestions. The views expressed herein are those of the authors and do not necessarily reflect the views of the National Bureau of Economic Research.

NBER working papers are circulated for discussion and comment purposes. They have not been peerreviewed or been subject to the review by the NBER Board of Directors that accompanies official NBER publications.

(C) 2012 by Daniel B. Jones, Werner Troesken, and Randall Walsh. All rights reserved. Short sections of text, not to exceed two paragraphs, may be quoted without explicit permission provided that full credit, including $\odot$ notice, is given to the source. 
A Poll Tax by any Other Name: The Political Economy of Disenfranchisement

Daniel B. Jones, Werner Troesken, and Randall Walsh

NBER Working Paper No. 18612

December 2012

JEL No. H0,J15,N11

\begin{abstract}
$\underline{\text { ABSTRACT }}$
In this paper, we examine the political economy of voting rights in the American South. We begin by measuring the impact of both formal laws and informal modes of voter suppression on African-American political participation. In contrast to prior research, we find evidence that both formal and informal modes of voter suppression were important and mutually reinforcing. Part of our analysis includes explicitly identifying the magnitude and causal effects of lynching on black voter participation. We then turn to analyzing to the relatively unexplored question of how disenfranchisement-and the accompanying shifts in political power-affected policy outcomes, congressional voting, and partisan control of state and federal legislatures.
\end{abstract}

Daniel B. Jones

Department of Economics

University of Pittsburgh

Pittsburgh, PA 15260

dbj3@pitt.edu

Werner Troesken

Department of Economics

University of Pittsburgh

Pittsburgh, PA 15260

and NBER

troesken@pitt.edu
Randall Walsh

Department of Economics

University of Pittsburgh

4901 WW Posvar Hall

230 S. Bouquet St.

Pittsburgh, PA 15260

and NBER

walshr@pitt.edu 
There is a clear consensus that historically African Americans have enjoyed fewer economic and political freedoms and reduced material and social welfare relative to whites. ${ }^{1}$ There is, however, much less consensus regarding the sources of this disadvantaged status. Many economists attribute the dearth of black economic and political advancement to informal institutions such as the crop lien system; ${ }^{2}$ paternalism; ${ }^{3}$ discrimination in labor markets; ${ }^{4}$ and more recently to social networks that have historically excluded disadvantaged groups (see, for example, Currarini et al. 2009). Others focus on formal laws and political decisions. For example, Margo (1990) shows how, by segregating blacks into separate and inferior schools, Southern governments impaired human capital accumulation both within and across generations. ${ }^{5}$ This, in turn, resulted in persistent racial disparities in economic and educational outcomes. ${ }^{6}$ Along the same lines, scholars across many disciplines attribute residential segregation and the creation of ghettoes to various federal policies and state laws inhibiting efforts by blacks to acquire mortgages and move into white neighborhoods (Cutler et al. 1997; Jackson 1985; Massey and Denton 1993).

Perhaps nowhere is the debate about formal and informal institutions more salient than in the literature on black disenfranchisement. As is well known, from shortly after the end of

${ }^{1}$ Compared to whites, African-Americans had lower literacy and schooling rates (Margo 1990, pp. 5-17); less occupational mobility (Fishback 1984; Craig and Fearn 1993; Whatley 1990; Wright 1996; Meeker and Kau 1977); more work-related injuries (Maloney 1998); lower wages (Smith 1984; Margo 1990, pp. 87-108); higher unemployment (Sundstrom 1992); lower life expectancies (Haines 2002; Ewbank 1987; Meeker 1976); reduced nutrition and stature (Carson 2009); higher infant mortality rates (Fishback et al. 2000; Haines 2002); and lower rates of home ownership (Collins and Margo 2001).

${ }^{2}$ Ransom and Sutch $(1977,2001)$ argue that the crop lien system locked poor black farmers in the South into debt peonage. For contrary interpretations, see Goldin (1979), Fishback (1989) and Irwin and O’Brien (2001).

${ }^{3}$ Alston and Ferrie $(1985,1993,1999)$ present evidence that paternalism worked as a protection racket that inhibited black mobility and undercut political support for a welfare state.

${ }^{4}$ See for instance: Neil and Johnson (1996); Rodgers and Spriggs(1996); and, Lang and Manove (2011). For a broad overview of this literature, see Lang and Lehmann (2011).

${ }^{5}$ See also Naidu (2012).

${ }^{6}$ See Badel (2010) for a treatment of these issues in a quantitative treatment of these issues in a dynamic locational equilibrium framework. 
Reconstruction to passage of the Voting Rights Act of 1965, southern blacks were denied the right to vote. In his now classic treatment, The Shaping of Southern Politics: Suffrage Restriction and the Establishment of the One-Party South, 1880-1910, J. Morgan Kousser (1974) argues that formal legal institutions such as poll taxes and literacy requirements were instrumental; without these laws and state enforcement of the laws, Southern racists never would have succeeded in denying blacks access to the ballot box. By contrast, in his seminal work, V.O. Key (1949) claims that formal laws were epiphenomenal, secondary to, and symptomatic of, a deeper set of social forces. In Key's words, the passage of poll taxes and literacy requirements at the state level were "a fait accompli brought about . . . by more fundamental political processes," where the phrase "fundamental political processes" refers to a host of informal modes of disenfranchisement initiated by private individuals, election officials, and organizations such as the Ku Klux Klan. Informal methods of voter disenfranchisement involved all manner of privately-initiated fraud, violence, and intimidation. Put another way, in Key's view, it was white animus toward blacks that mattered; the actions of the state merely reflected the preferences of the white populace and the white populace sought to suppress black political action through every means possible.

In this paper, we examine the political economy of voting rights in the American South. We begin by measuring the impact of both formal laws and informal modes of voter suppression on African-American political participation. While previous scholarship tends to emphasize the impact of either formal or informal institutions to the exclusion of the other, our analysis suggests a middle-way path: we find that both formal and informal institutions undercut black political participation, and that formal and informal modes of disenfranchisement were mutually re-enforcing. In particular, we present the strongest empirical evidence to date of the primal role 
played by informal activities in the loss of suffrage by southern blacks; not only identifying the relative magnitude of these activities but also providing the first empirical evidence of the link between violence (lynchings) and black disenfranchisement in the post-Reconstruction south. We additionally provide suggestive evidence of the role that party control of the election process (election judges, poll locations and times, etc.) played in disenfranchising southern blacks. On the other hand, our work suggests that the adoption of formal laws establishing poll taxes and literacy requirements, while not the primary drivers of disenfranchisement, did hasten the total disenfranchisement of blacks by approximately ten to thirteen years.

After analyzing the processes that disenfranchised blacks, we turn to the relatively unexplored question of how disenfranchisement-and the accompanying shifts in political poweraffected policy outcomes. We examine this question on both the extensive margin (the composition of legislatures) and the intensive margin (congressional voting behavior, conditional on party affiliation). It is generally believed that disenfranchising southern blacks impacted legislation on issues of economic policy and race. This belief has both logical and historical appeal. During Reconstruction, when recently emancipated slaves had access to the ballot box, blacks were able to form coalitions with white Republicans and promote a legislative agenda that, at least at the federal level, was friendly to African-American interests. Between 1866 and 1875, Congress passed and enacted four civil rights laws designed to guarantee blacks equal access to the voting booth, housing, hotel accommodations, private property, the administration of justice, and other rights and privileges. Although the courts eventually struck down parts of the civil rights laws, these measures illustrate how black interests could affect positive political change by forming coalitions with white Republicans, so long as blacks had access to the ballot. ${ }^{7}$

\footnotetext{
${ }^{7}$ See Civil Rights Cases, 109 U.S. 3 (1883)
} 
Only when blacks were disenfranchised were Southern legislatures able to wholly undo these federal protections.

To measure the effects of disenfranchisement on policy, we evaluate the voting records of southern congressmen. This analysis builds on a simple historical observation about Southern politics: because blacks were a minority in so many districts, they could only garner political power by forming coalitions with white Republicans. The opportunity to work in coalition with Republican interests increased the legislative impact of the franchise for the country's minority black population. By the same token, black votes were key to Republican efforts to build an electoral majority. In evaluating the impact of black political disenfranchisement on voting on Republican priorities, we use the well-known Poole-Rosenthal DW-NOMINATE scores. ${ }^{8}$ As a way of capturing the effects of disenfranchisement on voting behavior over policies directly relevant to black voters, we identify 12 key house floor votes on issues related to civil rights and suffrage. We then evaluate legislative voting records on these bills. To measure the effects of disenfranchisement on the extensive margin of policy - that is, which party is elected - we gather data on the party control of state legislatures. With these data, we measure, in both absolute and relative terms, the extent to which formal and informal methods of disenfranchisement altered the party composition and control of state legislatures. We also gather data on congressional election outcomes to assess the likelihood of a Democrat being elected to office before and after disenfranchisement. Presumably, as blacks were denied access to the ballot box and lost whatever political power they had, Democrats would have cemented their hold on the political process.

Consistent with our findings regarding the path to disenfranchisement, we find that both formal and informal methods of disenfranchisement are important for explaining changes in the

\footnotetext{
${ }^{8}$ See Poole and Rosenthal (1997).
} 
composition of state legislatures and the election of Democrats to Congress. Further, with the loss of franchise, the relationship between the size of a district's black population and representative voting on issues important to black interests switches from a significant and policy relevant positive relationship to a significant negative relationship. Finally, we document that the coalition between black and Republican interests yield results for Republican concerns as well. We find that when southern blacks had the franchise, the presence of a large black population in a given Congressional district was associated with the adoption of more conservative policies at both the extensive (election of republicans) and intensive (congressional voting - given party) margins. To our knowledge, ours is the first work to quantify these relationships. ${ }^{9}$

\section{A Brief History of Disenfranchisement}

Over the course of the late nineteenth and early twentieth century, state legislatures throughout the American South passed laws designed to restrict and forestall black political participation. ${ }^{10}$ We call these laws franchise restriction laws. Most franchise restriction laws fall into one of three categories: the poll tax, literacy requirements, and ballot box laws. Poll tax laws required individuals to provide evidence that they have paid their "poll tax" for the current year (and in some cases required evidence that individuals were current over a long-number of years) in order to vote. Literacy-test laws typically required individuals to read and explain a portion of the

\footnotetext{
${ }^{9}$ The two papers in economics most closely related this analysis are Naidu (2012) which identifies a causal link between disenfranchisement and reductions in state level spending on black schools and a recent paper by Cascio and Washington (2012), which finds that the Voting Rights Act of 1965 (which reversed the processes we analyze and returned the franchise to southern blacks) led to dramatic increases in black voter participation and induced a shift in the distribution of state aid toward localities with large black populations.

${ }^{10}$ For an excellent historical treatment of the Southern disenfranchisement of blacks see Perman (2001).
} 
state constitution, to the arbitrary satisfaction of an election official, prior to voting. Finally, several states passed collections of onerous election laws that required individuals to cast separate ballots for different offices into a set of up to 8 different ballot boxes (invalidating all votes by an individual if even one ballot was miscast), blocked the use of party symbols or color coding on ballots, and barred any assistance in navigating the complicated voting procedure by imposing a "secret ballot" requirement. One might, therefore, consider ballot box laws as a type of literacy test. Accordingly, in our empirical analysis, we collapse the ballot box and literacy test laws into a single treatment.

Table 1 lists all of the franchise restriction laws passed by Southern states between 1877 and 1910. ${ }^{11}$ Except for Georgia and Virginia, which passed their first poll tax as soon as Reconstruction ended, Southern states passed their first poll tax laws after 1889 and before 1905. Arkansas and Virginia passed multiple poll tax laws because earlier measures were struck down by the courts or were repealed and later revived by the legislature. Seven of the eleven states passed laws requiring a literacy test to establish voting eligibility. Mostly, these laws were enacted during the 1890 s or very early 1900 s. Ballot box measures were passed by every state in the South except Alabama, Georgia, and Virginia. Outside of Florida, which passed its law in 1889 , all of the ballot-box laws were enacted during the 1890 s.

The question that first motivated our research (and a long list of prominent scholars before us) is directed at understanding the efficacy of these laws: did they drive disenfranchisement, or were black voter participation rates already trending down even before their passage so that blacks would have been disenfranchised even without their passage? With

\footnotetext{
${ }^{11}$ We include the state of Texas in Table 1 for completeness. However, we exclude Texas from our subsequent analysis for two reasons. First, having been recently admitted to the union, Texas' postreconstruction experience was different from that of the other southern states. Second, and more importantly, the voting data for Texas appears to be systematically corrupted, with voter turnout rates recorded in the data that are unbelievably high -- often exceeding county populations.
} 
the right data, answering this question would be a simple econometric exercise: compile a panel of Southern states and, using a difference-in-differences set up, identify how franchise restriction laws alter the level and trend in black voter participation rates. The difficulty arises because voter participation rates for nineteenth and early twentieth century are aggregated across racial groups and are not reported separately for blacks and whites. To address this problem, Kousser for example, works one state at a time and uses ecological decomposition techniques. He computes mean suffrage changes for the periods immediately preceding and following passage of a combination of a literacy test and poll tax. He finds that suffrage rates dropped less in the period directly preceding the passage of these laws than they did in the period immediately following their passage. Based on this analysis, Kousser concludes that "the relatively small declines in Negro voting previous to disfranchisement [laws]" were important only to the extent that they facilitated the passage of poll taxes and literacy tests.

As a way of previewing our turnout analysis, Figure 1 summarizes the relationship between percent black and voter participation in Mississippi counties for the years 1876, 1888, 1892 and 1904. Notice that for 1876, while Reconstruction was still in play and federal troops still occupied parts of the South to prevent violence at the polls, the estimated relationship is positive, and voter turnout rises slightly with the proportion of the population that is black. This suggests that blacks were voting at higher rates than whites in Mississippi at this point in time, and/or that as the proportion of the population that was black rose (along with black political influence) it spurred whites to vote at higher rates. In either case, the pattern suggests a high degree of black political participation, which is consistent with the available anecdotal and fragmentary quantitative evidence. Yet by 1888, the relationship has reversed itself and increases in percent black are associated with sharp reductions in voter turnout. Just four years 
later, disenfranchisement is almost complete: to see this note that for both 1892 and 1904, as percent black approaches 100 percent, predicted turnout is almost zero. This basic pattern is repeated across all southern states over this time period. In our formal analysis, we explore the extent to which the relationship between voter turnout and black population level changed as a result of the implementation of poll taxes, literacy requirements, and ballot-box measures. Because of a lack of directly measured data on black turnout rates, in our turnout analysis we are forced to infer turnout rates based on ecological decompositions that are in spirit similar to this graphical analysis.

While we are sensitive to general concerns about ecological decompositions, we are confident of our approach and the interpretations that flow from that approach. The primary concern is that systematic patterns that we observe at the county-level between voter turnout and percent black are driven by white responses to the relative size of the black population. There are several reasons why we do not think that this is a plausible explanation for the results we present below. First, our analysis is focused on federal elections. Thus, the relevant electorate to which white voters should respond is at the Congressional District and/or State level. We base our analysis on inter-county variation and as a result this source of bias should be attenuated. Second, a large number of our counties contain populations that are more than $65 \%$ black. Explaining the magnitude of the changes we see in voting turnout in these counties based on white response to black populations would require unrealistically large shifts in the behavior of these white voters. Third, and perhaps most important, the patterns that we see in the data are inconsistent with this explanation. Relative turnout in black counties is decreasing as anti-black activism (both formal and informal) is increasing. If turnout patterns were driven by white response to black voters, we should expect to see white turnout increasing in highly black 
districts as Democrats and vigilante groups such as the Klan moved aggressively to restore the "Solid South". Fourth, our results are robust to the inclusion of a broad set of interacted fixed effects and trends. Finally, variation in our imputed measures of disenfranchisement have the expected statistical relationship to both our measures of informal disenfranchisement activities and the behavior of elected officials. These observations and the strong internal consistency that appears in our analysis suggest our approach is sound.

\section{Identifying the Causes of Disenfranchisement}

Before turning to the specifics of empirical strategy, a few words about data are in order. We use county-level data on election turnout in Congressional and Presidential Elections. ${ }^{12}$ The data were originally compiled by Jerome Clubb, William Flanigan, and Nancy Zingale. ${ }^{13}$ The original dataset reports total votes cast at the county-level for every congressional and presidential election between 1840 and 1972. We merge a subset of the years from this dataset with county-level population data to create panels of year-by-county turnout measures - one panel for congressional elections and one panel for presidential elections. These turnout measures are constructed simply as total votes cast divided by total population in a given county and year. Our final data set covers voter turnout data for congressional and presidential elections and the percent of each county's population that is black for the years 1872 to 1912 . In later analysis the data are also aggregated at the congressional district level. Limitations inherent in

\footnotetext{
${ }^{12}$ In later analyses, we use state-level data on gubernatorial election turnout. We omit gubernatorial elections from this particular analysis because of a lack of readily available data on county-level turnout in these elections.

${ }^{13}$ Electoral Data for Counties in the United States: Presidential and Congressional Races, 1840-1972. This dataset is publicly available online at http://www.icpsr.umich.edu/ (study number 8611).
} 
the available census data and occasional changes in county boundaries provide challenges on this front, and these challenges will be identified and discussed below.

Percent black is computed simply as total black population divided by total population in a given county and year. ${ }^{14}$ The counts of total black population and total population are taken from the 1860-1920 Decennial Censuses of Population. In most cases, we linearly interpolate between the two nearest Census years to obtain intercensal estimates of each of these counts and the corresponding percent black. One challenge in constructing the data is the fact that a number of new counties are created during the time period of interest. The creation of these new counties is accompanied by changes in the boundaries of existing counties. When this occurs, linear interpolation misrepresents changes in the percent of the population that is black within a county in non-Census years. For instance, suppose that a county's boundaries change in 1876 in a way that increases the percentage of the population that is black. It would be inappropriate to use the change in the black population in that county between the 1870 and 1880 Censuses to construct a continuous linear growth rate for all years within this decade, when in reality there is a discrete jump at 1876 .

To address this issue, we identify all distinct "versions" of each county throughout the panel, where a county is coded as a new "county version" each time that its boundaries change. Using this approach, we construct percent black using only Census data from the same county version. Specifically, we begin by identifying new counties that appear in each of the decennial

\footnotetext{
${ }^{14}$ One might also be interested in the percent of the voting-eligible population that is black. However, there is not sufficient information in all of the Censuses to consistently construct such a measure. In particular, the 1870 and 1880 Censuses do not report counts of population that are broken down by race, gender, and age.
} 
Censuses. Then, we identify (1) the specific year that each new county was created and (2) the surrounding counties that were modified in order to create this county. ${ }^{15}$

There are two categories of problem counties to address: counties that are newly created and counties that are modified. Of 841 counties in our sample, 643 (76 percent) counties exist and are unmodified during the entire period of interest (1875-1912). 78 counties are newly created. 102 counties are modified once (including several of the created counties) and 11 are modified twice. For a newly created county, total and black populations for the few years prior to its first year in the Census are estimated using a linear extrapolation of these counts from the two following Censuses. For instance, to obtain percent black in 1876 for a county that appears in 1876 we linearly extrapolate the rates of change in total and black population back based on the trend between 1880 (the first Census for which the county is observed) and 1890 .

For pre-existing but modified counties, we conduct a similar procedure with the added complication that we must extrapolate from future Censuses to obtain estimates for the new "county version" and we must extrapolate from previous Censuses to obtain estimates for the pre-existing county version. To make this clear, consider the pre-existing counties that were modified to create a new county. Estimates of total and black population for years strictly between 1870 and 1876 are constructed using rates of growth from the 1860 and 1870 Censuses. Estimates for 1876 and the remaining years of the decade are constructed using rates of growth from the 1880 and 1890 Censuses. ${ }^{16}$

\footnotetext{
${ }^{15}$ We use the Atlas of Historical County Boundaries to accomplish this. This resource can be found at http://publications.newberry.org/ahcbp/. Using the Atlas, we manually record the date that a new county is created and the counties that were modified to create it.

${ }^{16}$ We lose six observations as a result of this method. In particular, to use this method to estimate percent black for non-Census years, there must be two Census observations of the relevant county version on either side of the change. Thus, if a county changes twice within one decade, we cannot construct percent black for any years in between the first and second changes.
} 


\section{The Relative Importance of Formal vs. Informal Disenfranchisement}

Our analysis begins with a series of cross-sectional regressions run separately for each unique state $\mathrm{x}$ presidential election pair $^{17}$. The goal is to show how the relationship between countylevel racial composition and voter turnout evolves over the study period. Our approach was previewed above in the discussion of Mississippi counties in figure 1; here, however, we develop a formal apparatus which, though simple, undergirds our approach to the relevant ecological decomposition. We start with the regression model:

$\#$ Voters $_{j t}=\alpha *$ White Population $_{j t}+\beta *$ Black P $_{\text {pulation }_{j t}}+\epsilon_{j t}$

where $j$ indexes county version and $t$ indexes election (year). For a given state $x$ presidential election pair, assuming that black and white turnout rates are independent of county demographic composition, the estimated coefficients from this regression $(\alpha$ and $\beta)$ recover white and black turnout percentages for each state in each election.

Ideally, we would like to observe black turnout rates and study the impact of disenfranchising interventions directly. As discussed above, such data do not exist, so we rely on an ecological decomposition approach that assumes that high turnout in a district with a high concentration of blacks implies a high black turnout rate, whereas low turnout -- perhaps after disenfranchisement -- implies low black turnout. One minor issue is that because our analysis

${ }^{17}$ Here we focus on presidential elections because data are missing for some states for some congressional elections -- making the visual presentation of the data that follows more difficult. In the statistical analysis that follows, our results are not sensitive to the choice of Presidential vs. Congressional turnout data. 
takes total white and black populations as controls and not the corresponding voting-eligible populations, our estimates of turnout and the impact of disenfranchisement will be smaller in magnitude than had we based our percentages on voting-eligible populations. ${ }^{18}$ However, as we are interested primarily in documenting changes in turnout in response to formal and informal interventions, this is a minor concern.

With these caveats in mind, once we have estimated equation (1), we can tie the estimated relationship to the fitted regression lines in the scatter plots from figure 1 above through the following relationship:

$$
\text { Turnout Pct } t_{j t}=\alpha+(\beta-\alpha) * \text { Pct Black } \text {. }_{j t}
$$

From equation (2) it is apparent that the slope of the fitted line in the Mississippi scatter plots recovers an estimate of the difference in mean turnout rates for blacks and whites.

For each state, Figure 2 plots the evolution over time of estimated white turnout $\alpha$ (diamonds), estimated black turnout $\beta$ (squares), and estimated black turnout as a percentage of estimated white turnout $\frac{\beta}{\alpha}$ (triangles). The vertical lines in the figure denote the years in which different ballot restrictions first came in to force. While there is substantial noise in the relationships, in all ten states the steady erosion of the black franchise is clear. In some

\footnotetext{
${ }^{18}$ As discussed above in the data section, due to limitations in the census data, we constructed our data based on black and white populations per county rather than voting eligible populations (race specific counts of males over the age of 18). In earlier versions of our work, we analyzed interpolated data for eligible voters - yielding results consistent with those presented here. However, our concern about potential biases that could be introduced by this interpolation led us to focus our analysis on turnout as a percentage of population. With the obvious limitation that systematic changes in the relative age compositions of the black and white populations could impart bias into our estimates. Such systematic changes do not seem to occur; the difference between the voting-eligible fraction of the white population and the same measure for the black population remains essentially constant over our study period.
} 
instances the importance of legalized ballot restrictions are readily apparent: the combination of poll tax, secret ballot and literacy test which all came into effect in Mississippi for the 1892 election; the poll tax and literacy test initially in effect in North Carolina in 1904; Tennessee's poll tax and multi-box ballot law effective for the 1892 election; and, the combination of literacy test and re-enactment of a poll tax in Virginia in effect for 1904. However, in the remaining states it is difficult to differentiate the effects of ballot restrictions from the secular trends; and in all instances (with the possible exception of Tennessee) the data suggest that the passage of legal ballot restrictions is preceded by an erosion of the black franchise.

Having summarized the data in figure 2, we turn now to a formal statistical analysis and adopt a more elaborate regression framework. Equation (3) presents our baseline specification:

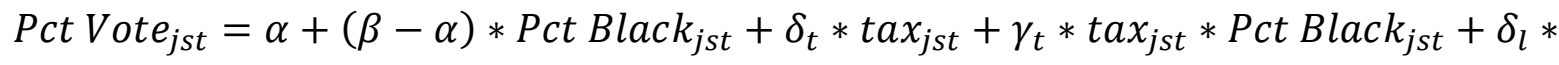

$$
\begin{aligned}
& \operatorname{lit}_{j s t}+\gamma_{l} * \operatorname{lit}_{j s t} * \quad \text { ct Black } k_{j s t}+\rho_{j}+\tau_{t}+\epsilon_{j s t} .
\end{aligned}
$$

Note that $j$ indexes county-version, $s$ indexes state and $t$ indexes election (year). County-version $\left(\rho_{j}\right)$ and year $\left(\tau_{t}\right)$ fixed effects are included in all specifications. Pct Vote and Pct Black are percentages based of the entire county population. Finally, $\operatorname{tax}$ is an indicator for a poll tax being in force and lit is an indicator that either an explicit literacy test or combination of ballot law and secret ballot were in force (see Table 1). For the regression analysis, our sample consists of elections from 1876 to 1912 . (Note that we start in 1876 because that is commonly seen as the last election of the Reconstruction era, and because, based on Figure 2, it is the peak of black turnout in many states). 
Tables 2.A and 2.B present results from these regressions for Congressional and Presidential elections. They decompose the overall reduction in Congressional (Presidential) election turnout from $14.9 \%(15.6 \%)$ to $7.16 \%(6.98 \%)$ that occurred between 1876 and 1912 into its component parts. ${ }^{19}$

Model 1 is our baseline specification from equation (3). Both the literacy test (along with secret ballot and multi-box laws) and the poll tax are predicted to have a significantly negative impact on black turnout. For instance, using data from Congressional elections (Table 2A), the model predicts that the poll tax decreases black turnout by roughly 2.2 percentage points relative to whites while the literacy test is predicted to decreases black turnout by roughly 9.0 percentage points relative to whites. Notably, the poll tax - which also impacted white voters - is predicted to significantly decrease their turnout as well, but at less than half the rate that it is predicted to decrease black turnout.

Model 2 adds a trend variable to equation (3). The trend captures the secular decrease in black franchise relative to white franchise (presumably driven by informal mechanisms such as fraud, violence and intimidation) that began following Reconstruction: (year - 1876) * percent black. The inclusion of this trend diminishes the estimated effects of the laws observed in Column 2, highlighting the importance of controlling for these informal means of disenfranchisement. One way to characterize these results is to compute how many years of secular/informal disenfranchisement (as measured by the interaction between trend and percent black) would be required to achieve the same level of disenfranchisement as occurred in response to the passage of the Poll Tax and Literacy laws. This "years" equivalency is reported in the row labeled "Impact of Poll Tax + Literacy Requirement." The results of model 2 suggest that these laws accelerated black disenfranchisement by roughly 22 to 31 years. However, model

\footnotetext{
${ }^{19}$ The figures quoted are cross-county averages.
} 
2 markedly underestimates the coefficient on trend because it fails to account for the change in trend that occurred following the passage of poll tax and literacy laws.

In models 3 and 4, we explicitly address the issue of changing trends. In model 3 we allow the trend to change after the imposition of both a poll tax and a literacy test through the inclusion of a "Post-law trend" variable and its interaction with percent black. Thus, the coefficient on "Trend X Pct. Black" can now be interpreted as the trend in turnout prior to formal disenfranchisement; that is, one might interpret the coefficient as a rough measure of the impact of informal methods of disenfranchisement that gradually stripped blacks of their voting rights even in the absence of poll taxes and literacy laws. Model 4 replicates model 3, but further strengthens identification through the inclusion of a fully interacted set of state and year fixed effects. This sharper identification comes at the expense of identifying the main effects of the laws. It is our most robust specification. With the exception of a slightly diminished predicted impact of the laws in model 4 relative to model 3 , results across the two specifications are roughly similar. Thus, in the remaining discussion we focus on Model 4. Using data from either congressional or presidential elections, we find that - in the absence of poll taxes or literacy tests - black turnout decreases by roughly 1.5 percentage points every four years relative to white turnout. Consistent with the suggestion that the laws themselves achieved near-total disenfranchisement, this trend in relative black turnout flattens significantly with the passage of formal disenfranchisement measures. Also, post-law black turnout decreases, relative to that of whites, by just 0.5 percentage points every four years following passage of the formal laws.

Finally, model 4 indicates that, if both poll taxes and literacy tests were passed simultaneously (as was often the case), black turnout would decrease by 4-5 percentage points (depending on whether we consider presidential or congressional data). Thus, it is clear that both 
informal and formal means of disenfranchising blacks had a meaningful impact. Based on our estimates, the introduction of disenfranchising polices accelerated total black disenfranchisement by approximately $11-12$ years.

The Path from Informal to Formal Disenfranchisement

While it is clear that informal and formal means of disenfranchisement each had significant direct impacts on restricting blacks' access to the ballots, years of violence and intimidation may have been causal in the sense that they paved the way to allowing the formal voting restrictions to pass (Kousser, 1974). In this section, we assess this claim. Put differently, we ask: To what extent was an increase in informal disenfranchisement a necessary condition for the establishment of formal disenfranchisement?

To answer this question, we construct a continuous state- and year-specific measure of disenfranchisement, which we then use to examine the growth in disenfranchisement immediately prior to the passage of poll tax and literacy laws. In particular, we begin with the $\beta$ (black turnout) estimates that were used to construct the graphs in Figure 2 (which resulted from state- and year- specific regressions of turnout on percent black). Within each state, we create a normalized $\beta^{\prime}$ which runs between 0 and 1 . Our "continuous disenfranchisement" measure is then constructed as $\left(1-\beta^{\prime}\right)$. Thus, for a particular state, when this value is equal to zero black voting rates are at their highest point and when the value reaches one disenfranchisement has reached its peak.

Table 3 reports the means of election-to-election (two year) growth in this continuous disenfranchisement measure prior to the enactment of disenfranchising laws. We report the 
increase in disenfranchisement experienced immediately prior to a law being enacted (that is, the difference between the measure one election prior to the law and the measure two elections prior to the law) and also the average growth across all other previous elections. Notably, there is a sharp increase in disenfranchisement one period prior to a law being introduced, which provides initial evidence that an acceleration in the degree of informal disenfranchisement is associated with the passage of formal mechanisms.

Table 4 provides more direct evidence. Here we estimate a Cox proportional hazard model, predicting the probability of passage of any policy (column 1), a literacy test or ballot law (column 2), or poll tax (column 3) as a function of the same one-period lagged increase in disenfranchisement as is reported in Table 3 . In column 1 we find that increasing growth in this measure is a significant predictor of introducing a law, providing further support for the means comparisons of table 3. Turning to columns 2 and 3, we find that this result is largely driven by the introduction of literacy tests/ballot laws. While the coefficient estimate is positive, this model does not provide a statistically significant prediction that growth in informal disenfranchisement accelerates the introduction of poll taxes.

To summarize our results, we find that both informal and formal means of disenfranchisement were important, with restrictive voting laws accelerating the process of disenfranchisement started by informal means. Moreover, tables 3 and 4 (in combination with the preceding results) suggest that informal disenfranchisement played two roles: actively disenfranchising blacks (at a rate of roughly $3 \%$ points per decade) but also paving the way to the passage of voting restrictions to achieve near-complete disenfranchisement of blacks.

\section{Direct Tests for Mechanisms of Informal Disenfranchisement}


To this point, our analysis has implicitly identified informal disenfranchisement as that disenfranchisement which cannot be explained by the passage of formal barriers to the vote. While the vast majority of these disenfranchising activities are unrecorded, we are able to identify and test two direct proxies for informal modes of disenfranchisement: (1) lynching and (2) Democratic control of state government which gave the party direct administrative control of the electoral process.

Historians and contemporary commentators have described the transition from Reconstruction-era suffrage to the implementation of "formal" disenfranchisement as taking place in three phases which can be characterized as: (1) the intimidation stage, (2) the dilution stage, and (3) disenfranchisement. ${ }^{20}$ Our lynching and state government control measures are meant speak to the first and second of these phases respectively. The "intimidation" stage is characterized by violence and threats of violence towards blacks. Democrats had not yet regained power and as such were unable to restrict blacks' ballot access through institutional mechanisms. Instead, blacks who supported Republicans were threatened with violence (and economic sanctions), allowing Democrats to gain some footing in returning to office despite facing largely black, pro-Republican electorates. Anecdotal evidence suggests that violence played a significant role. For instance, when Democrats regained power of the state legislature in North Carolina for the first time since Reconstruction, "Klan activity was reported in at least ten of the fifteen counties gained by the conservatives, and the conservatives victory was due less to an increase in their vote than to a decline in that of the Republicans" (Olsen, 1980). While such anecdotal evidence abounds, we are aware of only one attempt to provide quantitative evidence of this

\footnotetext{
${ }^{20}$ For contemporary references, see for instance Hamm (1899), Dunning (1901) and Poe (1902). For examples of the treatment of these phases of disenfranchisement by historians, see for instance Perman (2001) and Kousser (1999). Kousser, in particular, is responsible for the language used here.
} 
relationship. As we discuss below, this prior work finds no evidence of a link between violence and disenfranchisement.

The "dilution" phase is characterized by fraud and government attempts to minimize the influence of the black electorate without yet formally preventing blacks from voting (as eventually occurs with the passage of laws such as literacy requirements an poll taxes). ${ }^{21}$ Once in control of state government, Democrats leveraged their control of the election apparatus, employing a variety of methods to maintain their power. Democratic governors were able to appoint their preferred agents to supervise elections. In some instances, this led to polling locations purposefully located a great distance from largely black communities or last-minute changes to polling locations of which only white voters were notified (Dunning, 1901). This also facilitated fraud and bribery that was both blatant and unpunished; Hamm (1899) for instance notes that "ballot boxes were stuffed with tissue ballots and forgery on tally sheets was freely committed." Gerrymandering was another widely used approach; an extreme example is Mississippi's "shoestring district" which packed most of the state's highly black communities into an electoral district three hundred miles long and twenty miles wide.

We cannot observe or measure the vast majority of these dilutive activities. However, a large number of these mechanisms are only possible if Democrats are in control of state government. Thus, controlling for the formal disenfranchising actions of government and level of electoral support for Democrats, the impact of these state-sponsored informal actions should appear in our data as a discontinuous drop in black voting that occurs after a Democrat takes control of the governors' office.

\footnotetext{
${ }^{21}$ Consistent with the extant literature, we classify the poll tax and literacy laws as formal barriers to black franchise. However, we note that one alternative interpretation of these laws was that while not erecting a "formal" barrier they instead empowered the party in control of the election mechanisms to become more successfull in their efforts at informal disenfranchisement through their unchecked discretion in the application of these laws.
} 


\section{Lynching}

While most all scholars agree that violence was used to suppress black voter turnout in the postReconstruction South, there is very little quantitative evidence establishing a causal link between violence and turnout, or in measuring the magnitude of that link. In the only quantitative assessment we are aware of, Kousser (1999) examines Republican vote share in a handful of counties that had experienced a violent incident in the year preceding an election. In most of the counties he examines, Republican vote share roughly matches the fraction of the population that is black, which he takes as suggestive evidence that violence did not lead to the "once and for all destruction of the Republican vote" that one might have expected.

Using a comprehensive database of lynchings that occurred in the south between 1882 and $1930^{22}$, we construct a more comprehensive county-level dataset that indicates which counties have experienced lynchings in the year preceding all biennial elections occurring between 1882 and 1912. We use this dataset to evaluate the empirical link between violence and disenfranchisement. Thus, we begin by extending our previous specifications to include a county-level indicator for the occurrence of a lynching within each given county in the year leading up to each election. We then fully interact this variable with percent black and the presence of a poll tax or literacy test/ballot law. For simplicity, we also collapse our controls for the presence of voting laws into a single indicator for the presence of either of these laws. For parsimony, we only report results from our most rigorous model specification, which includes

\footnotetext{
${ }^{22}$ We use the "Historical American Lynching" (HAL) data collection, which is constructed and made available by Elizabeth Hines and Eliza Steelwater (http://people.uncw.edu/hinese). The data records lynchings for all of the states in our sample except for Virginia. The original lynching-level database indicates the race of the victim. In constructing our dataset, we only use lynchings with black victims.
} 
controls for county fixed effects, state-year fixed effects, and trends. Simpler specifications yield similar (but stronger) results.

We begin with the coefficients on "\% black X lynching" and "\% black X Lynching X Law," which estimate the differential impact of a within-county lynching on black turnout before and after the introduction of formal disenfranchising policies. These coefficients are reported in Column 1 of Table 5, with estimates from Congressional elections in Panel A and Presidential elections in Panel B. The estimates imply that when no formal disenfranchising policies have been passed lynching decreases black turnout by roughly 1-2 percentage points (relative to white turnout). This negative impact disappears once formal disenfranchising polices are in place. At least with regard to the signs of the coefficients, this is what we would expect: the presence of laws, typically associated with Democratic control of government, achieves almost total disenfranchisement. As such, lynching only affects turnout in the absence of such laws.

However, these results - particularly when examining presidential elections - are relatively weak. There are two potential explanations for this finding. First, there are relatively few lynchings in our data. This fact paired with the smaller number of presidential elections may drive the lack of precision in Panel B. Second, and perhaps more importantly, although a lynching occurs within a particular county it is likely to impact turnout in surrounding areas as well. That is, this first specification might conflate treatment and control: many "treated counties" are coded as though they are in the "control group." This would lead our included State $X$ Year fixed effects to absorb some of the general treatment effect.

To address the second issue, we broaden our definition of the lynching "treatment," considering an observation to be treated if a lynching occurred either within the given county or in a neighboring county. A county is considered "neighboring" if it is less than 100 miles from 
the reference county (measured from county centroid to county centroid). Model 2 replaces the within-county treatment with the within-100 miles treatment. For increased flexibility, model 3 includes both measures to allow for differential impacts as a function of distance from the lynching. In model 3, the within-county and within 100 miles measures are constructed to be mutually exclusive. The "within 100 miles" coefficients should therefore be interpreted as the impact of a lynching that occurs in a closely neighboring county.

Relative to model 1, models 2 and 3 generate results that are both larger in magnitude and more precise, suggesting that the impact of a lynching does extend beyond the location of the lynching itself and serves as a more general form of intimidation. Model 2 predicts that a lynching within 100 miles decreases turnout by 2 to 4 percentage points prior to disenfranchisement, with little impact afterwards. Model 3 confirms the existence of both a within-county and neighboring county effect with the within-county effect being roughly $45 \%$ greater in magnitude than the neighboring county effect. Overall, our results suggest that the within-county change is between 3 and 6 percentage points. For comparison, this effect is roughly 2 to 3 times larger than the estimated effect of a poll tax under the same empirical specification (Table 2, Model 4). ${ }^{23}$

Are these effects genuinely driven by the intimidation associated with lynching? An alternative explanation is that our lynching measure merely serves as a proxy for some unobserved characteristic of the legal environment that may be depressing turnout. While this would be instructive in its own right, it would not be the direct indication of "informal" disenfranchisement that we are attempting to provide in this section. To assess this possibility, model 4 extends model 3 by interacting the coefficients of interest with an indicator variable set

\footnotetext{
${ }^{23}$ Of course, the black turnout rate is substantially lower by the time poll taxes and literacy tests are introduced, so comparisons between percentage point changes are made for illustrative purposes only.
} 
to one when the neighboring-county lynching is in a different state. If our lynching measures are picking up characteristics of the state legal environment, we would expect to see very little impact of lynchings that are within 100 miles but out of state. Model 4 suggests that this is not the case. In presidential elections, the effect is identical regardless of whether the nearby lynching is in- or out-of-state. In congressional elections, the impact of an out-of-state lynching is marginally smaller, but still significantly negative.

\section{Control of Government}

We now examine the impact of a sitting Democratic governor (at the time of an election) on black turnout. When a Democrat is elected Governor, the party takes control of the state's election machinery and gains power to appoint election judges and officials. This in turn empowers the party to pursue the types of informal activities that characterized the "dilution" stage of informal disenfranchisement.

There are two potentially important sources of endogeneity between black turnout and Democratic control of state government. First, any other unobserved factors that are associated with depressed black voter turnout will also likely be associated with increased electoral success for Democrats. However, if changes in party control of the election apparatus results in access to new modes of informal disenfranchisement then there should be a discrete drop in black turnout once a Democratic governor is in power. This is in contrast to factors which are not associated with actual control of the governorship. The impact of these factors should vary continuously and thus can be controlled for by incorporating in our models flexible functional forms of 
gubernatorial vote share, as well as controls for the proportion of legislative seats held by Democrats.

The second potential confounder is the possibility that control of the Governor's office is associated with other formal means of disenfranchisement - beyond the literacy tests/ballot laws and poll taxes for which we control. Given our review of the available information we believe that the laws that we have identified represent a major proportion of the formal rules adopted to disenfranchise blacks. We do however concede that one interpretation of the results of this particular set of analyses is that it captures the net effect of all formal and informal disenfranchisement associated with Democratic control of the levers of state - exclusive of those laws specifically modeled in our analysis.

We take as our "treatment" an indicator variable that is equal to one if the governor in office at the time of an election is a Democrat. ${ }^{24}$ We include as controls a quadratic in the Democratic vote share in the most recent Governor's race. These controls, as well as the Democratic governor indicator, are fully interacted with percent black. To more fully capture the state political environment, we also include controls for the composition of the state legislature in a subset of the regressions. ${ }^{25}$

Table 6 reports the impact of a Democratic governor on black voter turnout. Here, we are primarily interested the interaction of percent black with our treatment (\% black X Dem. governor) - reported in columns 1 and 3 . To provide a parallel to the analysis of lynching, in columns 2 and 4 we report specifications which include the interaction of percent black, Democrat governor, and the presence of a law (\% black X Dem. gov. X Law). However, in this

\footnotetext{
${ }^{24}$ We observe two third-party governors in our dataset - a "Readjuster" and an "Anti-lottery Democrat." In both cases, they are closely aligned (and thus recoded) as either Republican or Democrats.

${ }^{25}$ In particular, we include controls for a quadratic function of fraction of the state legislature that are Democrats (separately for both upper and lower houses). When included, these state legislature controls are also fully interacted with percent black and the presence of a formal policy.
} 
specific analysis, Models 1 and 3 are our preferred specifications - for two reasons. First, unlike lynching, it is less clear that we should expect a difference in the impact of a sitting Democratic governor before and after a suffrage-restricting policy is passed. Just as a Democrat can interfere with the election process informally prior to the passage of a law, a Democrat can also allow loose and potentially harsher interpretations of suffrage-restriction laws after they have passed. Second, and perhaps more importantly, because passage of literacy tests and poll taxes are so closely linked to the election of Democratic Governors, there is very little independent variation in these two measures. This problem is most acute the models that include both time trends and legislative controls.$^{26}$

Considering results for both Congressional and Presidential elections, Models 1 and 3 predict that when a state has a Democratic governor black turnout is reduced by between 3.5 and 6 percentage points. Under the tighter identification strategy in Model 3, we get a prediction that black voter turnout was reduced by between 4.5 (4.25) percentage points in Congressional (Presidential) elections. Models 2 and 4 provide some weak evidence that this effect may be higher with the passage of a poll tax or literacy test. However, we do not place much emphasis on these results because, as already stated, there is a lack of post-law observations where Democrats are not in control; of a total 115 post-law state-year combinations, there is a nonDemocratic governor in just five instances.

To summarize, in this section we more explicitly explored the impact of "informal" disenfranchisement on turnout using two proxies motivated by the historical narrative of disenfranchisement: (1) lynching and (2) Democratic control of state government, which provided the Democratic Party control of the election machinery. Qualitatively, our results are

\footnotetext{
${ }^{26}$ This problem is most acute in the data for Presidential elections because we have roughly half as many Presidential election observations as we do for Congressional elections.
} 
consistent with what one might expect: lynching and Democratic control of government, even before the introduction of a law, suppresses turnout. What is somewhat surprising is the magnitude of the effects: both lynching and Democratic control generate relative turnout reductions that exceed our estimates of the impact of poll taxes and literacy laws. To some extent this lends credence to Key's "fait accompli" argument. At a minimum, however, these results emphasize the importance of viewing disenfranchisement as a gradual, continuous process accomplished by the collective impact and interaction of informal and formal measures. Moving into the next section, these findings motivate us to employ both discrete, policy-based measures and continuous measures of disenfranchisement in analyzing the impact of disenfranchisement on electoral outcomes and Congressional voting behavior.

\section{The impact of disenfranchisement on policy outcomes}

We now turn to perhaps the most novel part of our analysis: an examination of how disenfranchising blacks affected legislative and policy outcomes during the late nineteenth and early twentieth century. In particular, and as already noted, disenfranchisement undermined the coalition of black voters and Republican politicians formed during the Reconstruction era. Hence, in this section we explore how the gradual weakening of this coalition affected the election of Republicans (extensive margin) and voting behavior within the congress of representatives of the two major parties (intensive margin). On the extensive margin, we assess the likelihood of a Democrat being elected to the United States House of Representatives (as a function of the racial composition of the electorate) and also explore the evolution of Democrats' 
control of state legislatures. On the intensive margin, we first study how politicians voted on bills of specific interest to black voters (civil rights bills). Then, using a measure of politicians' ideology based on their roll-call voting behavior (Poole \& Rosenthal's DW-NOMINATE scores), we study the impact that disenfranchisement had on the location of policy positions (voting behavior) of both Congressional Democrats and Republicans relative to the fiscal ideologies of these two parties.

\section{Data}

In addition to panel data on disenfranchising laws and the constructed "continuous disenfranchisement" measure discussed above, we utilize several supplementary data sources in the remaining analysis. First, for all district-level analyses, we construct race and population measures at the congressional district level by aggregating county-level Census data. ${ }^{27}$ As before, we obtain intercensal estimates of population through simple linear interpolation of Census data. Table 7 summarizes this district-level measure of black population for Census years within the relevant time span. Notably, the black population is very high in a majority of counties; even in 1910 (when average black population is at its lowest point), blacks make up at least $10 \%$ of the population in more than $95 \%$ of congressional districts.

Data on the composition of state legislatures is taken from the Partisan Division of American State Governments, $1834-1985 .^{28}$ The data include the numbers of legislators by party

\footnotetext{
${ }^{27}$ In most cases, counties fully map into congressional districts. When this is the case, we simply aggregate county-level population data to create congressional district-level data. In some cases, counties are split across multiple congressional districts, by town and or City Ward. When possible, we allocate town and/or City Ward-level data to the appropriate congressional district.

${ }^{28}$ Compiled by Dean Burnham (ICPSR Study No. 16).
} 
for every state legislature (upper house and lower house) between 1834-1986, from which we construct "fraction democrat" for each observation between 1872-1910.

Data on the election and behavior of US Representative is taken from the Database of United States Congressional Historical Statistics, 1789-1989 (ICPSR Study No. 3371). This database includes several tables; relevant to this study are:

- Election Table: includes one observation for each candidate in an election; provides party affiliation for all candidates and congressional district of election.

- Serves Table: one observation for each term served by each representative; provides party affiliation and congressional district served.

- Roll Call Table: includes one observation for every roll call vote that every representative participated in.

We keep only southern state observations that are from the relevant time period (1872-1910, plus a handful of Roll Call Votes between 1870-1872). The bills we examine are summarized in the Table 8 . By focusing on this set of bills, we attempt to capture all prominent civil rights-related roll call votes in the relevant time period.

Finally, as a measure of politicians' voting behavior, we use the first dimension of Poole \& Rosenthal's DW-NOMINATE score. This dimension of the DW-NOMINATE score locates a politician along a left-right axis based on their voting patterns in each particular Congress relative to others in the same Congress. Increasingly positive DW-NOMINATE scores indicate a politician who is farther right (Republican-held positions) on economic issues, while increasingly negative scores indicate a politician who is farther left (Democrat-held positions). One final issue 
to note is that the dispersion of DW-Nominate scores varies across Congresses. To increase the comparability of the DW-Nominate scores across congresses we normalize these scores, dividing each individual's score for a given congress by the standard deviation of scores within that Congress. Our findings are not sensitive to this normalization.

\section{General empirical strategy}

In the following analyses we are interested in the relationship between disenfranchisement interacted with the percentage of an electorate that is black and a variety of outcomes. These include the likelihood of democrat being elected, civil rights roll-call voting, and DW-Nominate scores. Our baseline specification for these analyses is:

$y_{d t}=\alpha+\beta_{1}(\text { pct.black })_{d t}+\beta_{2}(\text { disenf })_{d t}+\beta_{3}(\text { pct. black })_{d t} \times(\text { disenf })_{d t}+[\text { controls }]_{d t}$

where (pct.black) $)_{d t}$ is the percentage of the population that is black within district $d$ at time $t$ and (disenf $)_{d t}$ is one of two measures of disenfranchisement. Of particular interest are the coefficients on "percent black" and "pct. black X disenfranchised." The former informs us of the influence that a largely black electorate can have on shaping policy outcomes when allowed to vote, while the latter documents the extent to which that influence diminishes as voting rights are stripped.

In some specifications (labeled "policy" in the tables that follow), the disenfranchisement measure is simply an indicator variable with (disenf) $d t=1$ if there is a disenfranchising policy (literacy test or poll tax) enacted in the state that district $d$ is located in at time $t$. For simplicity, 
throughout this section we assess the impact of the presence of any disenfranchising policy, rather than separating the impacts of literacy tests and poll taxes as in the previous section. In other specifications (labeled "cont. disenf." in tables that follow), (disenf) $d t$ is our constructed continuous disenfranchisement measure.

The dependent variable $y_{d t}$ and additional controls vary with the question of interest, but all specifications include state and year fixed effects. We also include controls for party affiliation. In the analysis of Congressional election outcomes, the unit of observation is a single election outcome and thus we are able to control for the number of terms that the incumbent had served at the time of the election. Whatever the unit of observation, however, standard errors are clustered at the congressional district level (with each change in a district's boundaries being coded as a new district.)

Throughout this section, "percent black" is re-centered around its mean, which varies across our different datasets but is roughly $42 \%$. This does not change the estimation or interpretation of the coefficient on "percent black" or any of the terms with which "percent black" is interacted. It merely allows us to interpret the "disenf." coefficient as the impact of disenfranchisement in the average county, rather than in a county with no black citizens. This facilitates easier interpretation of the estimated coefficients as most counties have relatively high percentage black (as documented in Table 7.)

Finally, when we assess the effect of disenfranchisement on party politics, we look at legislatures rather than individual representatives/candidates. Accordingly, in regressions looking at the party composition of legislatures, we regress "fraction of members of the legislature that are Democrats" on some measure of disenfranchisement, either policy indicators 
or the continuous measure. Again, state and year fixed effects are included. Bootstrapped standard errors are clustered at the state-level.

Results: Political outcomes on the extensive margin

This section documents the impact that disenfranchisement had on the election of politicians (and in turn, the election of policies). Democrats pushed disenfranchisement forward (at least partially) with the goal of reducing Republicans' influence, so not surprisingly they were the party to benefit from disenfranchisement. In our analysis of the extensive margin we first examine the impact of disenfranchisement on the partisan composition of state legislatures and then estimate the impact of disenfranchisement on the likelihood that a Democrat will succeed in an election for the US House of Representatives in a Southern district.

Table 9 documents Democrats' gains at the state legislature level. Taking as the unit of observation a state legislative term. The table reports the results of regressing the fraction of members of each legislature that are Democrats on our measures of disenfranchisement, for both Upper Houses (columns 1 and 3) and Lower Houses (columns 2 and 4). In columns 1 and 2 our results suggest that a formal anti-black voting policy (such as a poll tax, literacy test, or ballot law) is in place, while in columns 3 and 4 we employ our constructed continuous measure which incorporates both formal and informal disenfranchisement.

Regardless of which measure we use, we find a significant increase in Democrat control as disenfranchisement takes hold. Notably, the magnitude of the effect of our continuous measure is much larger. Recall that the continuous measures captures the effects of both formal and informal modes of disenfranchising black voters. Thus, the larger magnitude of coefficients 
on the continuous measure (which therefore indirectly contains the "policy" measure) emphasizes the importance of both of these mechanisms in determining the relative partisan compositions of the state legislatures.

In Table 10 we evaluate the impact of disenfranchisement on Congressional elections Taking each election for US House of Representatives (within the relevant states and time period) as the unit of observation, we estimate linear probability models assessing the likelihood that a Democrat is elected as a function of the electoral environment they face (the racial composition of the electorate and disenfranchisement status). Whether we measure disenfranchisement strictly with respect to formal policies (column 1) or using our more general continuous measure (column 2), two important patterns emerge, both of which are more pronounced under the use of our continuous measure of disenfranchisement (Column 2). First, when blacks have access to the ballot, the presence of a large number of blacks within a district markedly reduces the probability that a Democrat wins the district (albeit insignificantly so when using the "policy" measure). Second, as blacks were stripped of voting rights, this influence not only disappeared but was reversed. The positive coefficients on "Disenf. X Pct. Black" demonstrate that Republicans' advantage in high-black districts shrank as disenfranchisement increased. More striking is the fact that the marginal impact of "pct. black" conditional on blacks being disenfranchised (the linear combination Pct. Black + (Disenf. X Pct. Black)) is also positive and significant. Thus, disenfranchisement accomplished more than eliminating Republicans' advantage: it also shifted the advantage to the Democrats, perhaps driven by white animosity towards blacks in high-black districts.

Results: Political outcomes on the intensive margin 
We conclude our analysis of the political economy of disenfranchisement by exploring its impact on the voting behavior of Congressional Representatives. We explicitly consider both sides of the Republicans' coalition with black voters. It is not surprising that the black franchise impacted congressional outcomes at the extensive margin, aiding the election of Republicans. Less clear is the impact that black voting had on the intensive margin. Did the black franchise just lead to the election of Republicans who strongly supported civil rights for blacks ex ante? Or, did the franchise actually empower black constituencies to demand stronger policy positions from Republicans once they were elected? Conversely, did large enfranchised black constituencies embolden Republican congressmen to take more partisan positions on economic issues? With these issues in mind, we first assess representatives' roll call voting behavior in the context of civil rights bills and then in the context of unrelated bills (as summarized by the first dimension of the DW-Nominate score.) In both sets of analyses, we first examine the impact of disenfranchisement on legislator voting behavior in general to provide some sense of how disenfranchisement shifted policy outcomes. We then examine how the disenfranchisement differentially impacted the behavior of Republicans and Democrats.

Pooling votes from all of the bills listed in Table 8, Table 11 presents the results of linear probability models assessing the likelihood that a representative voted against the interest of blacks. Column 1 uses the simple "policy" indicator as our measure of disenfranchisement, while column 2 uses the continuous measure. ${ }^{29}$ As before, the results are qualitatively similar regardless of which measure is used. First - and unsurprisingly - Republicans are less likely to

\footnotetext{
${ }^{29}$ We have fewer observations in Column 2 because our continuous measure only goes as far back as 1872 and several roll call votes of interest take place before 1872. Dropping the pre-1872 bills from column 1 to achieve a set of bills directly comparable to column 2 does not substantially change the existing results.
} 
vote against the interest of blacks. However, conditional on party affiliation, we find that the likelihood of voting anti-black varies substantially with the degree of disenfranchisement and the percent of a representative's electorate that is black. In particular, when blacks have access to the ballots, representatives from increasingly black districts are significantly less likely to vote against the interest of blacks. However, as disenfranchisement takes hold, these representatives become significantly more likely to vote anti-black (the linear combination of Pct. Black and (Disenf. X Pct. Black) coefficients is positive and significant.) This, we think, is a striking finding, highlighting how large black populations in a given place promoted black political interests before disenfranchisement but undermined them afterward. In columns 3 and 4, we repeat the analysis from columns 1 and 2 but allow for a differential response by Democrats and Republicans. While the responses of legislators from the two parties move in the same direction with respect to percent black and disenfranchisement, columns 3 and 4 demonstrate that Republicans largely drive the results. Republicans from high-black districts are significantly less likely to vote anti-black prior to disenfranchisement, while both Democrats and Republicans from high-black districts are more likely to vote against the interest of blacks after disenfranchisement.

These patterns of course mirror our findings from the previous section. When blacks have the franchise, democrats are at a disadvantage in high-black districts and representatives from high-black districts (controlling for party) are more willing to support black interests. With disenfranchisement, Democrats gain a relative advantage in high-black districts and representatives actually become more antagonistic to black policy concerns than are their Democratic colleagues in low-black districts. The combination of these results provides evidence of the strength and importance of the role that the black franchise plaid in facilitating black 
access to the political process through their coalition with Republican interests. Further, they highlight the fact that loss of the franchise not only led to the loss of access to the political process, but actually paved the way to the election of legislators who actively worked against the interests of the black populations living within their districts.

Finally, we examine how this coalition (and its demise) affected voting on Republican interests, exclusive of civil rights. Tables $12 \mathrm{a}$ and $12 \mathrm{~b}$ reports the results of regressions that take as the dependent variable the first dimension of the DW-Nominate score. Recall that the DWNominate score places each representative (with one observation per congress) along a left-right spectrum based on how they voted on economic-related issues. Increasingly positive (negative) scores are associated with increasingly conservative (liberal) voting records.

In Table 12a, we employ the same general empirical specification that has been used throughout this section, including state and year fixed effects. In Table 12b, we take advantage of the fact that most congressmen serve in multiple congresses and include congressman fixed effects. ${ }^{30}$ This allows us to better identify how a politician reacts to a changing electorate, whereas the state and year fixed effects specifications may partially capture a changing electorate's propensity to elect a more (or less) extreme candidate. Results are qualitatively similar regardless of which approach we use.

Models 1 and 2 (in both Tables 12a and 12b) estimate the average impact of disenfranchisement and percent black on policy outcomes (as measured by DW-Nominate scores) using each of our two measures of disenfranchisement. ${ }^{31}$ The significant positive

\footnotetext{
${ }^{30}$ This approach is not feasible in the analysis of voting on civil rights bills, as we do not work with consecutive congresses there. Thus, there are far fewer repeated observations of individuals.

${ }^{31}$ A shortcoming of this approach is that because the sample consists of every representative from every Congress (between 1872-1910), any individual who served multiple terms in Congress appears in the dataset several times. To address this issue, we have run alternative specifications which aggregate the data to the representative level, averaging DW-Nominate score and relevant covariates across all of an
} 
coefficient on "pct. black" suggests that, controlling for party, in the presence of a black franchise large black constituencies lead legislators to adopt more conservative voting behavior. However, this result is eliminated with disenfranchisement. Despite the strong relationship that exists in the absence of a policy, once a policy is enacted there is no statistical relationship between the between percent black within a representative's district and his voting behavior. Again, this seems striking. It shows that black disenfranchisement not only affected legislative voting on civil-rights types of issues, but on a broad range of public policies. To our knowledge, no previous scholarship has documented empirically such an effect.

Note that unlike our previous analysis, there is no actual reversal in the impact of black constituencies on the intensive voting margin. In other words, under disenfranchisement we do not see large black populations being associated with increasingly Democratic voting positions. Also of interest is that the result here is not more pronounced when we use the continuous measure of disenfranchisement (and in some cases is insignificant where the policy dummy picks up a significant relationship). Recall that the continuous measure in some sense (albeit indirectly) captures both the effects of formal and informal disenfranchisement. Thus, this can be interpreted as suggestive evidence that, in the context of legislative roll-call votes, it is primarily the formal disenfranchisement policies that influence behavior. As before, in Models 3 and 4, we explore whether these results vary by party. Here, the results are mostly driven by Democrat voting behavior. That is, we find that - prior to disenfranchisement - Democrats from high black districts are forced to adopt positions closer to those of Republicans. This is no longer true after disenfranchisement.

individual representative's terms. The results are essentially identical whether aggregated to representative-level or not, so we report only main specifications here. 


\section{Concluding Remarks}

The central conclusions of this paper are twofold. First, we consider the political economy of the path to disenfranchisement. In doing so, we provide a new quantitative assessment of the Key-Kousser debate over the relative importance of formal vs. informal efforts to disenfranchise black voters. While Kousser was correct in arguing that legal institutions were an important instrument of political disenfranchisement, he overstated their importance when he claimed that they were significantly more important than violence and informal institutions. Specifically, the evidence that we provide suggests that formal disenfranchisement hastened an extant process of informal disenfranchisement on the order of 10 to 12 years. We also provide empirical evidence that passage of disenfranchising legislation was predicated on increases in the level of informal disenfranchisement. Furthermore, we provide statistical evidence supporting the role of two different informal mechanisms to explain informal disenfranchisement. Of most note is our finding that having a lynching occur within a given county in the year prior to a given election reduces black turnout by approximately three to six percentage points; lynchings in proximate counties suppress black turnout by two to four percentage points.

Our second set of results regard the impact of disenfranchisement on legislative outcomes. This is an area that to date has received minimal quantitative analysis. We find that through their coalition with Republican interests the franchise gave black voters an effective political voice. However, once the franchise was removed black citizens in predominately black congressional districts not only lost their political voice, but faced representatives that were actively hostile to their interests. While this is an intuitive finding, our regressions are the first to document its magnitude and significance. In addition, and perhaps more surprising, we also find 
that, by undermining the coalition between blacks and Republicans, voting on issues unrelated to civil rights also changed, moving toward more liberal, pro-Democrat outcomes. One mechanism driving these shifts was a move from a competitive political system, where there was a real chance for Republicans to win office, to one where the Democratic Party dominated state legislatures and faced little risk of defeat from Republicans. 


\section{References}

Alston, Lee J. and Joseph P. Ferrie. 1985. "Labor Costs, Paternalism, and Loyalty in Southern Agriculture: A Constraint on the Growth of the Welfare State." Journal of Economic History, 45:95-117.

Alston, Lee J. and Joseph P. Ferrie. 1993. "Paternalism in Agricultural Labor Contracts in the U.S. South: Implications for the Growth of the Welfare State." American Economic Review, 83:852-76.

Alston, Lee J. and Joseph P. Ferrie. 1999. Paternalism and the American Welfare State: Economics, Politics, and Institutions in the U.S. South, 1865-1965. Cambridge: Cambridge University Press.

Badel, Alejandro. 2010. "Understanding Permanent Black-White Earnings Inequality." Federal Reserve Bank of St. Louis Working Paper \#2010-047B.

Boustan, Leah Platt and Robert A. Margo. 2009. "Race, Segregation, and Postal Employment: New Evidence on Spatial Mismatch.” Journal of Urban Economics, 65:1-10.

Carson, Scott Alan. 2009. "African-American and White Inequality in the Nineteenth Century American South: A Biological Comparison.” Journal of Population Economics, 22:739-55.

Cascio, Elizabeth U. and Ebonya L. Washington. 2012. "Valuing the Vote: The Redistribution of Voting Rights and State Funds Following the Voting Rights Act of 1965." NBER Working Paper No. 17776. Cambridge, MA.

Collins, William J. and Robert A. Margo. 2001. "Race and Home Ownership: A Century-Long View." Explorations in Economic History, 38:68-92.

Collins, William J. and Robert A. Margo. 2003. "Race and the Value of Owner-Occupied Housing, 1940-1960." Regional Science and Urban Economics, 33:255-86.

Craig, Lee A. and Robert M. Fearn. 1993. "Wage Discrimination and Occupational Crowding in a Competitive Industry: Evidence from the American Whaling Industry." Journal of Economic History, 53:123-38.

Cutler, David M., Edward L. Glaeser, and Jacob L. Vigdor. 1999. "The Rise and Decline of the American Ghetto." Journal of Political Economy, 107:455-506.

Dunning, William A. 1901. "The Undoing of Reconstruction," The Atlantic Monthly" Vol 88. No 528: 437-449.

Ewbank, Douglas C. 1987. "History of Black Mortality and Health before 1940." Milbank Quarterly, 65 (Supplement 1):101-28. 
Fishback, Price. 1984. "Segregation in Job Hierarchies: West Virginia Coal Mining, 19061932." Journal of Economic History, 44:755-74.

Foote, Christopher L., Warren C. Whatley, Gavin Wright. 2003. "Arbitraging a Discriminatory Labor Market: Black Workers at the Ford Motor Company, 1918-1947." Journal of Labor Economics, 21:493-532.

Hamm, Walter C. 1899. "The Three Phases of Colored Suffrage," The North American Review, Vol. 168, No. 508: 285-296.

Irwin, James R. and Anthony Patrick O’Brien. 2001. "Economic Progress in the Postbellum South? African-American Farmers in the Mississippi Delta, 1880-1910," Explorations in Economic History, 38:166-180.

Jackson, Kenneth T. 1985. Crabgrass Frontier: The Suburbanization of the United States. New York: Oxford University Press.

King, Gary. 1997. A Solution to the Ecological Inference Problem: Reconstructing Individual Behavior from Aggregate Data. Princeton: Princeton University Press.

Kousser, J. Morgan. 1974. The Shaping of Southern Politics: Suffrage Restriction and the Establishment of the One-Party South 1880-1910. New Haven: Yale University Press.

Kousser, J. Morgan. 1999. Colorblind Injustice: Minority Voting Rights and the Undoing of the Second Reconstruction. Chapel Hill: University of North Carolina Press.

Lang, Kevin and Jee-Yeon Lehmann. 2011. "Racial Discrimination in the Labor Market: Theory and Empirics," National Bureau of Economic Research Working Paper \#17450.

Lang, Kevin and Michael Manove. 2011. "Education and Labor Market Discrimination," American Economic Review, 95(4):1327-40.

Maloney, Thomas N. 1998. "Racial Segregation, Working Conditions, and Workers' Health: Evidence from the A.M. Byers Company, 1916-1930." Explorations in Economic History, 35:272-95.

Maloney, Thomas N. and Warren C. Whatley. 1995. "Making the Effort: The Contours of Racial Discrimination in Detroit's Labor Markets, 1920-1940." Journal of Economic History, 55:465-93.

Margo, Robert A. 1990. Race and Schooling in the South, 1880-1950: An Economic History. Chicago: University of Chicago Press.

Massey, Douglas S. and Nancy A. Denton. 1993. American Apartheid: Segregation and the Making of the Underclass. Cambridge: Harvard University Press. 
Meeker, Edward. 1976. "Mortality Trends of Southern Blacks, 1850-1910: Some Preliminary Findings." Explorations in Economic History, 13:13-42.

Naidu, Suresh. 2012. "Suffrage, Schooling, and Sorting in the Post-Bellum U.S. South." NBER Working Paper, No. 18129. Cambridge, MA.

Neal, Derek A. and William R. Johnson. 1996. "The role of Premarket Factors in Black-White Wage Differences," Journal of Political Economy, 104(5): 869-95.

Olsen, Otto. 1980. "North Carolina: An Incongruous Presence." Reconstruction and Redemption in the South. Louisiana State University Press, pp. 156-201.

Perman, Michael. 2001. Struggle for Mastery: Disfranchisement in the South, 1888-1908. Chapel Hill: University of North Carolina Press.

Poe, Clarence H. 1902. "Suffrage Restriction in the South; Its Causes and Consequences." North American Review. Vol. 175, No. 551 (Oct., 1902), pp. 534-543.

Poole, Keith, and Howard Rosenthal. 1997. Congress: A Political-Economic History of Roll Call Voting. New York : Oxford University Press.

Ransom, Roger and Richard Sutch. 1977. One Kind of Freedom: The Economic Consequences of Emancipation. Cambridge: Cambridge University Press.

Ransom, Roger and Richard Sutch. 2001. "One Kind of Freedom: Reconsidered (and Turbo Charged)," Explorations in Economic History, 38:6-39.

Redding, Kent and David R. James. 2001. "Estimating Levels and Modeling Determinants of Black and White Voter Turnout in the South: 1880 to 1912," Historical Methods, 34:4: 141-158.

Redding, Kent. 2003. Making Race, Making Power. Champaign-Urbana: University of Illinois Press.

Rodgers, William M. and William E. Spriggs. 1996. "The Effect of Federal Contractor Status on Racial Differences in Establishment-Level Employment Shares: 1979-1992," American Economic Review, 41(8): 1589-1613.

Sundstrom, William A. 1992. "Last Hired, First Fired? Unemployment and Urban Black Workers During the Great Depression.” Journal of Economic History, 52:415-29.

Sundstrom, William A. 1994. "The Color Line: Racial Norms and Discrimination in Urban Labor Markets, 1910-1950.” Journal of Economic History, 54:382-96. 
Table 1: Years in Effect for Voting Laws in the Southern States

\begin{tabular}{lccc}
\hline State & Poll Tax & Literacy Test & Secret Ballot/Multi-Box \\
\hline Alabama & 1902 & 1903 & $1892^{\mathrm{b}}$ \\
Arkansas & $1893-1904^{\mathrm{a}}, 1910$ & & $1889^{\mathrm{c}}$ \\
Florida & 1889 & 1908 & \\
Georgia & 1877 & 1899 & $1896^{\mathrm{d}}$ \\
Louisiana & 1900 & 1892 & $1891^{\mathrm{e}}$ \\
Mississippi & 1891 & 1902 & $1899^{\mathrm{c}}$ \\
North Carolina & 1902 & 1896 & $1882^{\mathrm{c}}$ \\
South Carolina & 1896 & & $1890^{\mathrm{f}}$ \\
Tennessee & 1890 & & \\
Texas & 1903 & 1902 & $1894^{\mathrm{h}}$ \\
Virginia & $1877-1882^{\mathrm{g}}, 1904$ & & \\
\hline
\end{tabular}

a. Invalidated by U.S. Circuit Court January 7, 1905, reenacted prior to the Election of 1910.

b. The Election Law of 1891 mandated a secret ballot and standardized ballots. In concert, these requirements were a type of de-facto literacy test. Illiterate voters could no-longer rely on party symbols and/or similar devices to vote straight party and the secret ballot requirement created barriers to voting assistance.

c. Several States adopted complicated "multi-box" election laws that required multiple ballots (typically 8) each to be placed in a separate ballot box. A mistake in filing a single ballot would disqualify all ballots - thus, these laws operated much like a de facto literacy test.

d. Combination of Secret Ballot requirement and an onerous change in registration requirements.

e. Secret Ballot.

f. Secret Ballot w/out Party Identifiers \& New Registration Law.

g. Virginia's Poll Tax was repealed 1882 and then re-instated in 1904.

h. Secret Ballot w/ out Party Identifiers

Sources: Alabama, Literacy Requirement \& Poll Tax- Revised Alabama State Constitution Adopted 1901; Arkansas, Poll Tax - state constitutional amendments ratified in 1892, Invalidated by U.S. Circuit Court due to electoral challenge January 7, 1905 (Knight v. Shelton), reinstated as an amendment to Arkansas Constitution in 1909. Secret Ballot - BRANAM C. "Another Look at Disfranchisement in Arkansas", 1888-1894. Arkansas Historical Quarterly. September 2010; 69(3):245-256; Florida, Multi-Box \& Poll Tax - Constitutional amendment of 1885 empowers state to adopt Poll-Tax \& Multi-Box adopted by legislature in 1889. See Perman, M. "Struggle for Mastery: Disenfranchisement in the South 1888-1908" 2001, UNC Press. \& Lee, R.W. "The Florida Election Canvassing System” Nova L. Rev. 851, spring, 2002.; Georgia, Poll Tax - Cumulative Poll Tax requirement included in 1877 Amendments to State Constitution. Literacy Test - Amendment to the state constitution in Fall of 1908.; Louisiana, Poll Tax \& Literacy Test - Amendments to the State Constitution adopted in 1898. Ballot Law Perman (2001).; Mississippi, Poll-Tax, Literacy Test \& Multi-Box - Amendments to the state constitutions adopted in 1890.; North Carolina, Poll Tax \& Literacy Test - Amendments to the State Constitution adopted August 1900, Multi-Box - Enacted by State Legislature on 6 March 1899.; South Carolina, Poll Tax \& Literacy Test - Amendments to State Constitution ratified December 1895. Multi-Box - Perman (2001).; Tennessee, Ballot \& Registration Laws - Legislative Acts of 1889 Ch.s 188, 207, 218 \& Legislative Acts of 1890 Ch. 23 - Ch. 25 . Poll Tax Legislative Acts of 1890, Ch. 26 Effective March 1890; Texas, Poll Tax - Amendment to State Constitution adopted November 1902. "American Government and Politics: The Poll Tax: The Case of Texas", Donald S. Strong The American Political Science Review Vol. 38, No. 4 (Aug., 1944), pp. 693-709.; Virginia, Poll Tax - Poll Tax requirement for voting established in the State Constitutional Amendments adopted November, 1876, subsequently removed in an Amendment to the State Constitution ratified in November, 1882. An Amendment to the State Constitution adopted by the State Legislature July,1902 reinstated the Poll Tax effective 1904. Literacy Requirement - established in constitutional amendments adopted by the state legislature July, 1902. Ballot Law - Acts of General Assembly 1894 Ch. 746 adopted March 1894. 
Table 2.A: Turnout Regressions - Congressional Elections

\begin{tabular}{|c|c|c|c|c|}
\hline VARIABLES & $\begin{array}{c}(1) \\
\text { Baseline }\end{array}$ & $\begin{array}{c}\text { (2) } \\
\text { Baseline w/ Trend }\end{array}$ & $\begin{array}{c}(3) \\
\text { Pre- and Post- } \\
\text { trends }\end{array}$ & $\begin{array}{c}\text { (4) } \\
\text { State X Year } \\
\text { Fixed-Effects }\end{array}$ \\
\hline Pct. Black & $\begin{array}{l}0.00781 \\
(0.0311)\end{array}$ & $\begin{array}{c}0.0304 \\
(0.0320)\end{array}$ & $\begin{array}{c}0.0568 \\
(0.0362)\end{array}$ & $\begin{array}{l}0.107 * * * \\
(0.0224)\end{array}$ \\
\hline Polltax & $\begin{array}{c}-0.0123 * * * \\
(0.00213)\end{array}$ & $\begin{array}{l}-0.0158 * * * \\
(0.00210)\end{array}$ & $\begin{array}{c}-0.0138 * * * \\
(0.00209)\end{array}$ & \\
\hline Polltax X Pct. black. & $\begin{array}{l}-0.0222 * * * \\
(0.00588)\end{array}$ & $\begin{array}{l}-0.00967 \\
(0.00630)\end{array}$ & $\begin{array}{r}-0.0159^{* *} \\
(0.00644)\end{array}$ & $\begin{array}{l}-0.0185 * * * \\
(0.00588)\end{array}$ \\
\hline Literacy & $\begin{array}{l}0.0129 * * * \\
(0.00255)\end{array}$ & $\begin{array}{l}-0.00204 \\
(0.00251)\end{array}$ & $\begin{array}{l}-0.00722^{* * *} \\
(0.00254)\end{array}$ & \\
\hline Lit. X Pct. Black & $\begin{array}{c}-0.0902 * * * \\
(0.00611)\end{array}$ & $\begin{array}{c}-0.0495 * * * \\
(0.00606)\end{array}$ & $\begin{array}{c}-0.0383^{* * * *} \\
(0.00627)\end{array}$ & $\begin{array}{c}-0.0289 * * * \\
(0.00562)\end{array}$ \\
\hline Trend X Pct. Black & & $\begin{array}{c}-0.00274 * * * \\
(0.000323)\end{array}$ & $\begin{array}{c}-0.00490 * * * \\
(0.000502)\end{array}$ & $\begin{array}{c}-0.00438 * * * \\
(0.000440)\end{array}$ \\
\hline Post-law trend & & & $\begin{array}{l}-0.00204 * * * \\
(0.000275)\end{array}$ & \\
\hline Post-law trend X Pct. black & & & $\begin{array}{l}0.00474 * * * \\
(0.000737)\end{array}$ & $\begin{array}{l}0.00491 * * * \\
(0.000718)\end{array}$ \\
\hline Constant & $\begin{array}{l}0.104 * * * \\
(0.0108)\end{array}$ & $\begin{array}{l}0.129 * * * \\
(0.0117)\end{array}$ & $\begin{array}{l}0.156^{* * *} \\
(0.0143)\end{array}$ & $\begin{array}{c}0.0747 * * * \\
(0.00787)\end{array}$ \\
\hline $\begin{array}{l}\text { Impact of Poll Tax }+ \text { Literacy } \\
\text { Requirement }\end{array}$ & & $\begin{array}{l}21.59 \text { years } \\
(x x x)\end{array}$ & $\begin{array}{l}11.06 \text { years } \\
(2.13)\end{array}$ & $\begin{array}{l}10.83 \text { years } \\
(2.15)\end{array}$ \\
\hline Year FE's & $\mathrm{X}$ & $\mathrm{X}$ & $\mathrm{X}$ & \\
\hline $\begin{array}{l}\text { State X Year FE's } \\
\text { County Version FE's }\end{array}$ & $\mathrm{X}$ & $\mathrm{X}$ & $\mathrm{X}$ & $\begin{array}{l}X \\
X\end{array}$ \\
\hline Observations & 12,273 & 12,273 & 12,273 & 12,273 \\
\hline R-squared & 0.722 & 0.727 & 0.731 & 0.826 \\
\hline
\end{tabular}

Robust standard errors in parentheses

$* * * \mathrm{p}<0.01, * * \mathrm{p}<0.05, * \mathrm{p}<0.1$

Clustered@County-Version Level 
Table 2.B: Turnout Regressions - Presidential Elections

\begin{tabular}{|c|c|c|c|c|}
\hline VARIABLES & $\begin{array}{c}(1) \\
\text { Baseline }\end{array}$ & $\begin{array}{c}(2) \\
\text { Baseline w/ Trend }\end{array}$ & $\begin{array}{c}(3) \\
\text { Pre- and Post- } \\
\text { trends } \\
\end{array}$ & $\begin{array}{c}(4) \\
\text { State X Year } \\
\text { Fixed-Effects } \\
\end{array}$ \\
\hline Pct. Black & $\begin{array}{c}0.0147 \\
(0.0205)\end{array}$ & $\begin{array}{l}0.0335^{*} \\
(0.0202)\end{array}$ & $\begin{array}{l}0.0368^{*} \\
(0.0221)\end{array}$ & $\begin{array}{l}0.0579 * * * \\
(0.0212)\end{array}$ \\
\hline Polltax & $\begin{array}{l}-0.0168 * * * \\
(0.00204)\end{array}$ & $\begin{array}{l}-0.0216^{* * *} \\
(0.00204)\end{array}$ & $\begin{array}{l}-0.0213 * * * \\
(0.00196)\end{array}$ & \\
\hline Polltax X Pct. black. & $\begin{array}{c}-0.0292 * * * \\
(0.00556)\end{array}$ & $\begin{array}{l}-0.0155^{* * *} \\
(0.00568)\end{array}$ & $\begin{array}{c}-0.0209 * * * \\
(0.00542)\end{array}$ & $\begin{array}{l}-0.0164 * * * \\
(0.00470)\end{array}$ \\
\hline Literacy & $\begin{array}{l}0.0207 * * * \\
(0.00235)\end{array}$ & $\begin{array}{c}0.00754 * * * \\
(0.00241)\end{array}$ & $\begin{array}{c}0.00642 * * * \\
(0.00237)\end{array}$ & \\
\hline Lit. X Pct. Black & $\begin{array}{l}-0.0869 * * * \\
(0.00550)\end{array}$ & $\begin{array}{c}-0.0535^{* * *} \\
(0.00627)\end{array}$ & $\begin{array}{c}-0.0486 * * * \\
(0.00604)\end{array}$ & $\begin{array}{c}-0.0258 * * * \\
(0.00555)\end{array}$ \\
\hline Trend X Pct. Black & & $\begin{array}{c}-0.00223 * * * \\
(0.000256)\end{array}$ & $\begin{array}{c}-0.00310^{* * *} \\
(0.000360)\end{array}$ & $\begin{array}{c}-0.00327^{* * *} \\
(0.000344)\end{array}$ \\
\hline Post-law trend & & & $\begin{array}{l}-0.000273 \\
(0.000241)\end{array}$ & \\
\hline Post-law trend X Pct. black & & & $\begin{array}{l}0.00269 * * * \\
(0.000545)\end{array}$ & $\begin{array}{l}0.00195 * * * \\
(0.000520)\end{array}$ \\
\hline Constant & $\begin{array}{l}0.103 * * * \\
(0.00771)\end{array}$ & $\begin{array}{l}0.126^{* * *} \\
(0.00817)\end{array}$ & $\begin{array}{l}0.129 * * * \\
(0.00946)\end{array}$ & $\begin{array}{l}0.0981 * * * \\
(0.00803)\end{array}$ \\
\hline $\begin{array}{l}\text { Impact of Poll Tax + Literacy } \\
\text { Requirement }\end{array}$ & & $\begin{array}{l}30.94 \text { years } \\
(x x x)\end{array}$ & $\begin{array}{c}22.44 \text { years } \\
(4.21)\end{array}$ & $\begin{array}{c}12.92 \text { years } \\
(2.82)\end{array}$ \\
\hline Year FE's & $\mathrm{X}$ & $\mathrm{X}$ & $\mathrm{X}$ & \\
\hline $\begin{array}{l}\text { State X Year FE's } \\
\text { County Version FE's }\end{array}$ & $\mathrm{X}$ & $\mathrm{X}$ & $\mathrm{X}$ & $\begin{array}{l}\mathrm{X} \\
\mathrm{X}\end{array}$ \\
\hline Observations & 7,765 & 7,765 & 7,765 & 7,765 \\
\hline R-squared & 0.794 & 0.797 & 0.800 & 0.867 \\
\hline
\end{tabular}

Robust standard errors in parentheses

$* * * \mathrm{p}<0.01, * * \mathrm{p}<0.05, * \mathrm{p}<0.1$

Clustered@County-Version Level 
Table 3: Means of growth in continuous disenfranchisement measure before laws

\begin{tabular}{cccc}
\hline & $(1)$ & $(2)$ & $(3)$ \\
& Any policy enacted & Literacy/Ballot law enacted & Poll tax enacted \\
\hline 1 election prior to law & 0.0383 & & \\
& $(0.0101)$ & 0.0431 & 0.0494 \\
1 election prior to law & 0.113 & $(0.00914)$ & $(0.00959)$ \\
& $(0.0239)$ & 0.0950 & 0.0908 \\
Observations & 80 & $(0.0256)$ & $(0.0244)$ \\
& & 104 & 91 \\
\hline
\end{tabular}

Table 4: Hazard Model - Prediction the introduction of a law

\begin{tabular}{lccc}
\hline & $(1)$ & $(2)$ & $(3)$ \\
VARIABLES & Any policy & Literacy/Ballot & Poll tax \\
\hline Lagged growth in & $11.83^{*}$ & & \\
disenf. measure & $(6.063)$ & $17.46^{*}$ & 7.001 \\
& & $(9.084)$ & $(5.053)$ \\
Observations & 80 & 104 & 91 \\
\hline
\end{tabular}

Standard errors in parentheses

$* * * \mathrm{p}<0.01,{ }^{* *} \mathrm{p}<0.05,{ }^{*} \mathrm{p}<0.1$ 
Table 5: The Impact of Lynching on Turnout

\begin{tabular}{|c|c|c|c|c|}
\hline VARIABLES & $(1)$ & $(2)$ & (3) & $(4)$ \\
\hline \multicolumn{5}{|l|}{ Panel A: Congressional elections } \\
\hline $\begin{array}{l}\text { \% black X Lynching } \\
\text { (within county) }\end{array}$ & $\begin{array}{l}-0.0211^{*} \\
(0.0115)\end{array}$ & & $\begin{array}{c}-0.0578 * * * \\
(0.0123)\end{array}$ & $\begin{array}{c}-0.0735 * * * \\
(0.0141)\end{array}$ \\
\hline $\begin{array}{l}\text { \% black X Lynching X Law } \\
\text { (within county) }\end{array}$ & $\begin{array}{l}0.0266^{* *} \\
(0.0127)\end{array}$ & & $\begin{array}{c}0.0710^{* * *} \\
(0.0155)\end{array}$ & $\begin{array}{c}0.0773 * * * \\
(0.0170)\end{array}$ \\
\hline $\begin{array}{l}\text { \% black X Lynching } \\
\text { (within 100mi) }\end{array}$ & & $\begin{array}{l}-0.0412 * * * \\
(0.00762)\end{array}$ & $\begin{array}{c}-0.0399 * * * \\
(0.00776)\end{array}$ & $\begin{array}{r}-0.0480^{* * *} \\
(0.00869)\end{array}$ \\
\hline $\begin{array}{l}\text { \% black X Lynching X Law } \\
\text { (within 100mi) }\end{array}$ & & $\begin{array}{r}0.0503 * * * \\
(0.00953)\end{array}$ & $\begin{array}{l}0.0486^{* * *} \\
(0.00955)\end{array}$ & $\begin{array}{c}0.0513^{* * *} \\
(0.0102)\end{array}$ \\
\hline $\begin{array}{l}\text { \% black X Lynching X Out-of-state } \\
\text { (within 100mi) }\end{array}$ & & & & $\begin{array}{l}0.0198^{* *} \\
(0.00778)\end{array}$ \\
\hline $\begin{array}{l}\% \text { black X Lynching X Law X Out-of-state } \\
\text { (within 100mi) }\end{array}$ & & & & $\begin{array}{l}-0.00689 \\
(0.00879)\end{array}$ \\
\hline \multicolumn{5}{|l|}{ Panel B: Presidential elections } \\
\hline $\begin{array}{l}\text { \% black X Lynching } \\
\text { (within county) }\end{array}$ & $\begin{array}{l}-0.0120 \\
(0.0150)\end{array}$ & & $\begin{array}{l}-0.0346^{*} \\
(0.0190)\end{array}$ & $\begin{array}{l}-0.0387^{*} \\
(0.0209)\end{array}$ \\
\hline $\begin{array}{l}\text { \% black X Lynching X Law } \\
\text { (within county) }\end{array}$ & $\begin{array}{c}0.0199 \\
(0.0150)\end{array}$ & & $\begin{array}{r}0.0498^{* *} \\
(0.0202)\end{array}$ & $\begin{array}{c}0.0567^{* * *} \\
(0.0214)\end{array}$ \\
\hline $\begin{array}{l}\text { \% black X Lynching } \\
\text { (within 100mi) }\end{array}$ & & $\begin{array}{c}-0.0242 * * \\
(0.0118)\end{array}$ & $\begin{array}{c}-0.0238 * * \\
(0.0118)\end{array}$ & $\begin{array}{c}-0.0263 * * \\
(0.0123)\end{array}$ \\
\hline $\begin{array}{l}\text { \% black X Lynching X Law } \\
\text { (within 100mi) }\end{array}$ & & $\begin{array}{c}0.0322 * * \\
(0.0128)\end{array}$ & $\begin{array}{c}0.0314 * * \\
(0.0126)\end{array}$ & $\begin{array}{c}0.0353^{* * *} \\
(0.0129)\end{array}$ \\
\hline $\begin{array}{l}\text { \% black X Lynching X Out-of-state } \\
\text { (within 100mi) }\end{array}$ & & & & $\begin{array}{c}0.00457 \\
(0.00847)\end{array}$ \\
\hline $\begin{array}{l}\text { \% black X Lynching X Law X Out-of-state } \\
\text { (within 100mi) }\end{array}$ & & & & $\begin{array}{l}-0.00663 \\
(0.00900)\end{array}$ \\
\hline
\end{tabular}

All specifications include county fixed effects, state-year fixed effects, and trends controls.

Standard errors are clustered at the county level. 
Table 6: The Impact of a Democratic Governor on Turnout

\begin{tabular}{|c|c|c|c|c|}
\hline VARIABLES & (1) & $(2)$ & (3) & (4) \\
\hline \multicolumn{5}{|l|}{ Panel A: Congressional elections } \\
\hline \% black X Dem. governor & $\begin{array}{c}-0.0618 * * * \\
(0.00624)\end{array}$ & $\begin{array}{c}-0.0420 * * * \\
(0.00848)\end{array}$ & $\begin{array}{c}-0.0452 * * * \\
(0.00590)\end{array}$ & $\begin{array}{c}-0.0398 * * * \\
(0.0110)\end{array}$ \\
\hline \% black X Dem. gov. X Law & & $\begin{array}{c}-0.00734 \\
(0.0138)\end{array}$ & & $\begin{array}{l}0.00383 \\
(0.0165)\end{array}$ \\
\hline \multicolumn{5}{|l|}{ Panel B: Presidential elections } \\
\hline \% black X Dem. governor & $\begin{array}{c}-0.0375^{* * *} \\
(0.00617)\end{array}$ & $\begin{array}{c}-0.0359 * * * \\
(0.0106)\end{array}$ & $\begin{array}{c}-0.0427 * * * \\
(0.00592)\end{array}$ & $\begin{array}{l}-0.0161 \\
(0.0138)\end{array}$ \\
\hline \% black X Dem. gov. X Law & & $\begin{array}{c}-0.0372 * * \\
(0.0150)\end{array}$ & & $\begin{array}{c}-0.0771 * * * \\
(0.0194)\end{array}$ \\
\hline County Version FEs & $\mathrm{X}$ & $\mathrm{X}$ & $\mathrm{X}$ & $\mathrm{X}$ \\
\hline Year FEs & $\mathrm{X}$ & $\mathrm{X}$ & $\mathrm{X}$ & $\mathrm{X}$ \\
\hline Trends & $\mathrm{X}$ & $\mathrm{X}$ & $\mathrm{X}$ & $\mathrm{X}$ \\
\hline Legislature composition controls & & & $\mathrm{X}$ & $\mathrm{X}$ \\
\hline $\begin{array}{l}\text { "Law" equals one for observations in } \mathrm{s} \\
\text { for Democratic governor's vote share } \mathrm{i} \\
\text { of these variables with percent black } \\
\text { fraction of upper house legislators wh } \\
\text { variables squared, and the full interacti } \\
\text { county-level -- in parentheses. } \\
* * * \mathrm{p}<0.01,{ }^{* *} \mathrm{p}<0.05,{ }^{*} \mathrm{p}<0.1\end{array}$ & $\begin{array}{l}\text { years where } \\
\text { ost recent ele } \\
\text { w". Specific } \\
\text { emocrats, fra } \\
\text { ese variables }\end{array}$ & $\begin{array}{l}\text { a poll tax or 1 } \\
\text { faced, (Dem. } \\
\text { with "legislatu } \\
\text { f lower house } \\
\text { rcent black anc }\end{array}$ & $\begin{array}{l}\text { test. All speci } \\
\text { or vote share) } \\
\text { position contr } \\
\text { ors who are } I \\
\text { " Robust stan }\end{array}$ & $\begin{array}{l}\text { S include contro } \\
\text { he full interactio } \\
\text { lude controls } \mathrm{f} \\
\text { ats, both of the } \\
\text { ors - clustered }\end{array}$ \\
\hline
\end{tabular}


Table 7: Congressional district-level fraction black by Census year

\begin{tabular}{cccc}
\hline Census year & Total districts & Mean & $5^{\text {th }}-95^{\text {th }}$ percentile \\
\hline 1880 & 68 & 0.46 & {$[0.13,0.69]$} \\
1890 & 74 & 0.42 & {$[0.11,0.67]$} \\
1900 & 76 & 0.41 & {$[0.10,0.65]$} \\
1910 & 84 & 0.39 & {$[0.09,0.65]$} \\
\hline
\end{tabular}


Table 8: Summary of civil rights bills assessed

\begin{tabular}{cccccc}
\hline & & \multicolumn{2}{c}{ Republicans } & \multicolumn{2}{c}{ Democrats } \\
Date of vote & Bill/Issue & Votes against & Votes for & Votes against & Votes for \\
\hline May 27, 1870 & First Civil Rights Act & 1 & 24 & 5 & 0 \\
April 19, 1871 & HR 320 & 4 & 17 & 16 & 0 \\
April 19, 1871 & HR 320 & 0 & 19 & 17 & 0 \\
January 15, 1872 & HR 500 & 8 & 8 & 0 & 15 \\
May 31, 1872 & Ku Klux Klan Act & 0 & 21 & 18 & 0 \\
June 20, 1874 & S. 1 & 7 & 26 & 15 & 1 \\
February 4, 1875 & HR 796 & 18 & 14 & 18 & 1 \\
February 4, 1875 & HR 796 & 8 & 26 & 17 & 2 \\
May 18, 1878 & Posse Comitatus Act & 6 & 1 & 1 & 52 \\
December 16, 1884 & Railroad Act & 0 & 3 & 48 & 2 \\
December 17, 1884 & Railroad Act & 7 & 0 & 0 & 54 \\
July 2, 1890 & Federal Control of & 1 & 8 & 60 & 0 \\
January 3, 1901 & Elections & Reapportionment & 0 & 6 & 38 \\
\hline
\end{tabular}

Table 9: Fraction of Democrat state legislators

\begin{tabular}{lcccc}
\hline & $\begin{array}{c}(1) \\
\text { policy }\end{array}$ & $\begin{array}{c}(2) \\
\text { policy }\end{array}$ & $\begin{array}{c}(3) \\
\text { cont. disenf. }\end{array}$ & $\begin{array}{c}(4) \\
\text { cont. disenf. }\end{array}$ \\
& & & & \\
Disenfranchisement & $0.0946^{*}$ & $0.0873^{*}$ & $0.233^{* *}$ & $0.174^{* *}$ \\
& $(0.0506)$ & $(0.0456)$ & $(0.0940)$ & $(0.0848)$ \\
Constant & $0.440^{* * *}$ & $0.487^{* * *}$ & $0.420^{* * *}$ & $0.471^{* * *}$ \\
& $(0.0809)$ & $(0.0692)$ & $(0.0922)$ & $(0.0757)$ \\
House & & & & \\
& Upper & Lower & Upper & Lower \\
Observations & & & & \\
R-squared & 180 & 180 & 180 & 180 \\
\hline Allspcifica & 0.613 & 0.645 & 0.582 & 0.606 \\
\hline
\end{tabular}

All specifications include state and year fixed effects. Bootstrapped standard errors (clustered at state-level) in parentheses.

$* * * \mathrm{p}<0.01, * * \mathrm{p}<0.05, * \mathrm{p}<0.1$ 
Table 10: Likelihood of a Democrat Winning a Congressional Election

(1) policy

\begin{tabular}{lcc} 
& policy & cont. disenf. \\
\hline & & \\
Pct. Black & -0.245 & $-0.521^{* *}$ \\
& $(0.161)$ & $(0.242)$ \\
Disenf. X Pct. Black & $0.500^{* * *}$ & $0.933^{* * *}$ \\
& $(0.160)$ & $(0.293)$ \\
Disenfranchisement & 0.0408 & $0.144^{* *}$ \\
& $(0.0302)$ & $(0.0616)$ \\
Constant & $0.500^{* * *}$ & $0.623^{* * *}$ \\
& $(0.115)$ & $(0.140)$ \\
\hline & & \\
Observations & 1,188 & 1,217 \\
R-squared & 0.188 & 0.198 \\
\hline Both specifications include controls for incumbents' number of terms served, plus \\
state and year fixed effects. Robust standard errors (clustered at congressional \\
district-level) in parentheses. & \\
$* * * \mathrm{p}<0.01, * * \mathrm{p}<0.05,{ }^{*} \mathrm{p}<0.1$ &
\end{tabular}


Table 11: Likelihood of voting anti-black on civil rights bills

\begin{tabular}{lcccc}
\hline & $(1)$ & $\begin{array}{c}(2) \\
\text { policy }\end{array}$ & $\begin{array}{c}(3) \\
\text { policy }\end{array}$ & $\begin{array}{c}(4) \\
\text { cont. disenf. }\end{array}$ \\
\hline & & & & \\
VARIABLES & $-0.277^{* *}$ & $-0.410^{* *}$ & 0.00109 & -0.0757 \\
& $(0.132)$ & $(0.197)$ & $(0.111)$ & $(0.215)$ \\
Disenf. X Pct. black & $0.563^{* * *}$ & $0.875^{* * *}$ & 0.151 & 0.230 \\
& $(0.181)$ & $(0.332)$ & $(0.164)$ & $(0.324)$ \\
Disenfranchised & -0.0414 & -0.00905 & -0.0164 & 0.125 \\
& $(0.0413)$ & $(0.102)$ & $(0.0401)$ & $(0.107)$ \\
Repub. X Pct. black & & & $-0.670^{* *}$ & -0.568 \\
& & & $(0.291)$ & $(0.378)$ \\
Repub. X Disenf. X Pct. black & & & $0.703^{* *}$ & 0.950 \\
& & & $(0.319)$ & $(0.676)$ \\
Repub. X Disenf. & & & $-0.297^{* * *}$ & $-0.687^{* * *}$ \\
& & & $(0.0630)$ & $(0.159)$ \\
Republican & $-0.690^{* * *}$ & $-0.688^{* * *}$ & $-0.656^{* * *}$ & $-0.562^{* * *}$ \\
& $(0.0541)$ & $(0.0562)$ & $(0.0594)$ & $(0.0721)$ \\
Constant & $1.177^{* * *}$ & $1.174^{* * *}$ & $1.181^{* * *}$ & $1.150^{* * *}$ \\
& $(0.0877)$ & $(0.0902)$ & $(0.0872)$ & $(0.0810)$ \\
Observations & & & & 489 \\
R-squared & 489 & 489 & 489 & 489 \\
\hline All & 0.666 & 0.666 & 0.683 & 0.697 \\
\hline
\end{tabular}

All specifications include state and bill fixed effects. Robust standard errors (clustered at congressional districtlevel) in parentheses.

$$
* * * \mathrm{p}<0.01, * * \mathrm{p}<0.05, * \mathrm{p}<0.1
$$


Table 12a: Partisanship of voting record (DW-Nominate score)

\begin{tabular}{|c|c|c|c|c|}
\hline & $\begin{array}{c}(1) \\
\text { policy }\end{array}$ & $\begin{array}{c}\text { (2) } \\
\text { cont. disenf. }\end{array}$ & $\begin{array}{c}(3) \\
\text { policy }\end{array}$ & $\begin{array}{c}\text { (4) } \\
\text { cont. disenf. }\end{array}$ \\
\hline Pct. black & $\begin{array}{c}0.264 * * * \\
(0.0825)\end{array}$ & $\begin{array}{c}0.257 * * \\
(0.112)\end{array}$ & $\begin{array}{c}0.286^{* * *} * \\
(0.0931)\end{array}$ & $\begin{array}{c}0.332 * * \\
(0.132)\end{array}$ \\
\hline Disenf. X Pct. black & $\begin{array}{c}-0.241 * * * \\
(0.0873)\end{array}$ & $\begin{array}{l}-0.220 \\
(0.145)\end{array}$ & $\begin{array}{c}-0.267 * * * \\
(0.0974)\end{array}$ & $\begin{array}{l}-0.325^{*} \\
(0.172)\end{array}$ \\
\hline Disenfranchised & $\begin{array}{l}-0.0330 \\
(0.0260)\end{array}$ & $\begin{array}{c}0.0317 \\
(0.0573)\end{array}$ & $\begin{array}{l}-0.0393 \\
(0.0265)\end{array}$ & $\begin{array}{l}0.00643 \\
(0.0601)\end{array}$ \\
\hline Repub. X Pct. black & & & $\begin{array}{c}-0.0767 \\
(0.170)\end{array}$ & $\begin{array}{l}-0.270 \\
(0.225)\end{array}$ \\
\hline Repub. X Disenf. X Pct. black & & & $\begin{array}{c}0.173 \\
(0.216)\end{array}$ & $\begin{array}{l}0.635 * \\
(0.334)\end{array}$ \\
\hline Repub. X Disenf. & & & $\begin{array}{c}0.0670 \\
(0.0617)\end{array}$ & $\begin{array}{l}0.213 * * \\
(0.0897)\end{array}$ \\
\hline Republican & $\begin{array}{c}1.992 * * * \\
(0.0314)\end{array}$ & $\begin{array}{c}1.998 * * * \\
(0.0312)\end{array}$ & $\begin{array}{l}1.975^{* * *} * \\
(0.0390)\end{array}$ & $\begin{array}{l}1.930 * * * \\
(0.0481)\end{array}$ \\
\hline Constant & $\begin{array}{c}-1.147 * * * \\
(0.0497)\end{array}$ & $\begin{array}{c}-1.125 * * * \\
(0.0518)\end{array}$ & $\begin{array}{c}-1.147 * * * \\
(0.0497)\end{array}$ & $\begin{array}{c}-1.125 * * * \\
(0.0518)\end{array}$ \\
\hline Observations & 1,487 & 1,487 & 1,487 & 1,487 \\
\hline R-squared & 0.903 & 0.903 & 0.903 & 0.903 \\
\hline
\end{tabular}

NOTE: Dependent variable is DW-Nominate score. Positive values indicate increasingly conservative (Republican) positions. Negative values indicate increasingly liberal (Democratic) positions.

All specifications include state and year fixed effects. Robust standard errors (clustered at congressional district-level) in parentheses.

$* * * \mathrm{p}<0.01, * * \mathrm{p}<0.05, * \mathrm{p}<0.1$ 
Table 12b: Partisanship of voting record (DW-Nominate score) with Congressman Fixed Effects

\begin{tabular}{lcccc}
\hline & $\begin{array}{c}(1) \\
\text { policy }\end{array}$ & $\begin{array}{c}(2) \\
\text { cont. disenf. }\end{array}$ & $\begin{array}{c}(3) \\
\text { policy }\end{array}$ & $\begin{array}{c}(4) \\
\text { cont. disenf. }\end{array}$ \\
\hline & & & & \\
Pct. black & $0.306^{*}$ & $0.414^{*}$ & $0.342^{*}$ & $0.477^{*}$ \\
& $(0.182)$ & $(0.248)$ & $(0.186)$ & $(0.258)$ \\
Disenf. X Pct. black & $-0.238^{* *}$ & -0.373 & $-0.287^{* *}$ & $-0.457^{*}$ \\
& $(0.102)$ & $(0.248)$ & $(0.118)$ & $(0.275)$ \\
Disenfranchised & $0.0918^{*}$ & 0.152 & $0.110^{*}$ & 0.185 \\
& $(0.0505)$ & $(0.124)$ & $(0.0561)$ & $(0.136)$ \\
Repub. X Pct. black & & & -0.634 & -1.231 \\
& & & $(0.568)$ & $(1.042)$ \\
Repub. X Disenf. X Pct. black & & & 0.422 & 0.898 \\
& & & $(0.348)$ & $(0.565)$ \\
Repub. X Disenf. & & & -0.133 & -0.298 \\
Republican & & & $(0.212)$ & $(0.229)$ \\
Constant & $-1.160^{* * *}$ & $-1.202^{* * *}$ & $-1.160^{* * *}$ & $-1.196^{* * *}$ \\
& $(0.0978)$ & $(0.128)$ & $(0.0948)$ & $(0.130)$ \\
Observations & & & & \\
R-squared & 1,487 & 1,487 & 1,487 & 1,487 \\
& 0.990 & 0.990 & 0.990 & 0.990 \\
& $0.306^{*}$ & $0.414^{*}$ & $0.342^{*}$ & $0.477^{*}$ \\
& $(0.182)$ & $(0.248)$ & $(0.186)$ & $(0.258)$ \\
\hline
\end{tabular}

NOTE: Dependent variable is DW-Nominate score. Positive values indicate increasingly conservative (Republican) positions. Negative values indicate increasingly liberal (Democratic) positions.

All specifications include congressman and year fixed effects. Robust standard errors (clustered at congressional district-level) in parentheses.

$* * * \mathrm{p}<0.01,{ }^{* *} \mathrm{p}<0.05,{ }^{*} \mathrm{p}<0.1$

Figure 1: Racial Composition and Presidential Election Turnout Rates (Mississippi, 1876-1904). 


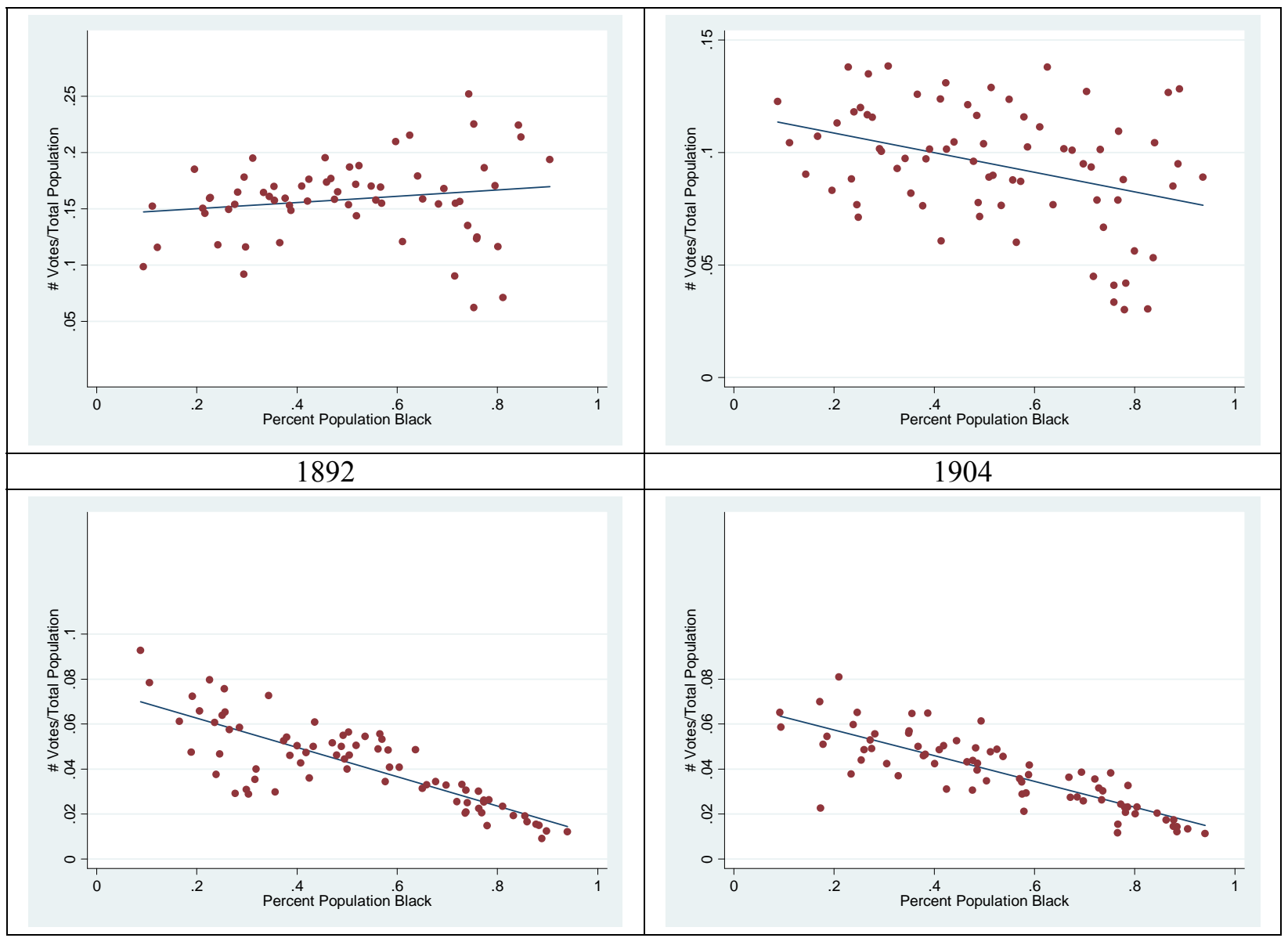


Figure 2 (Part I): Cross-Sectional Relationship Between Pct. Black and Voter Turnout

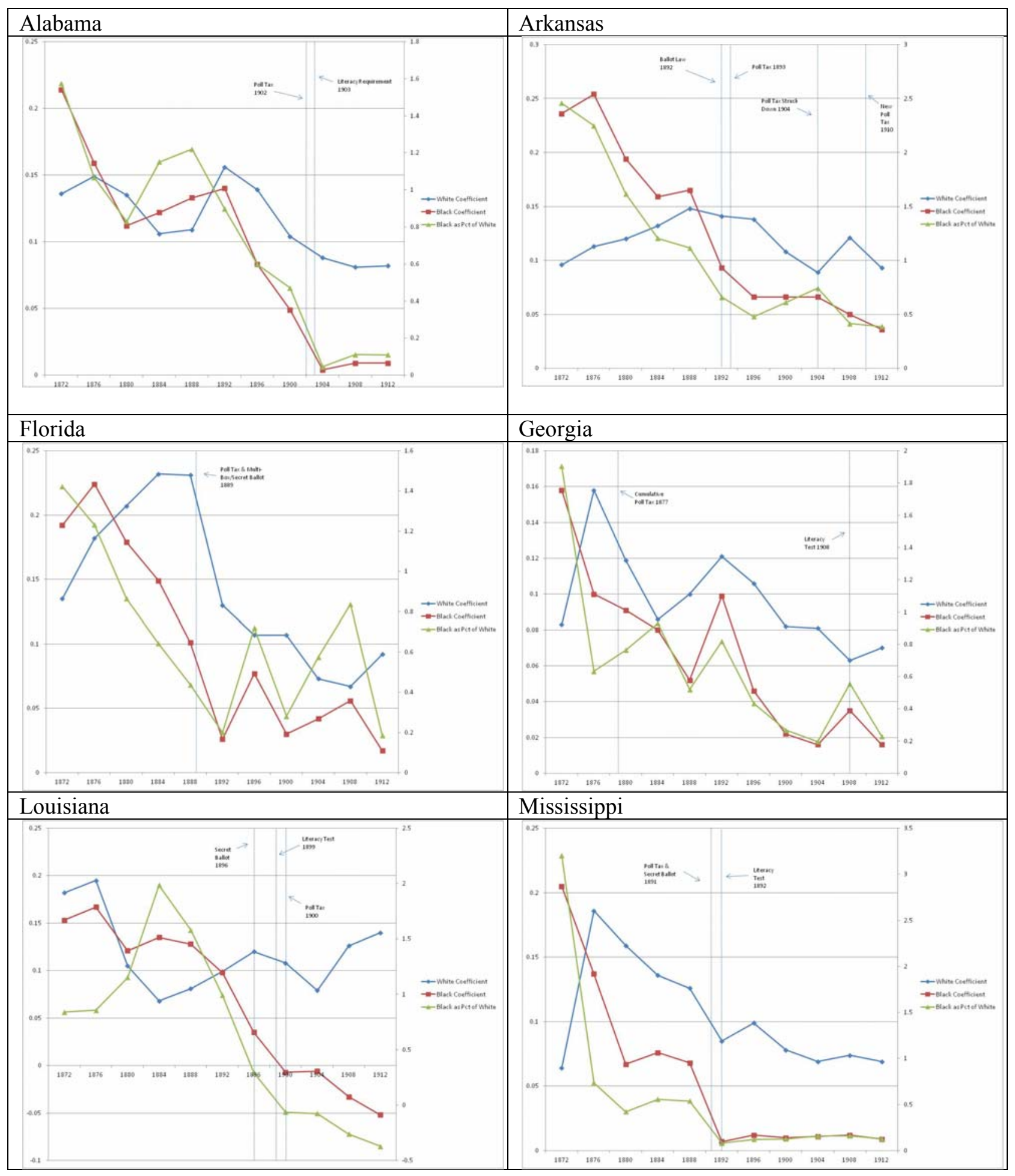


Figure 2 (Part II): Cross-Sectional Relationship Between Pct. Black and Voter Turnout

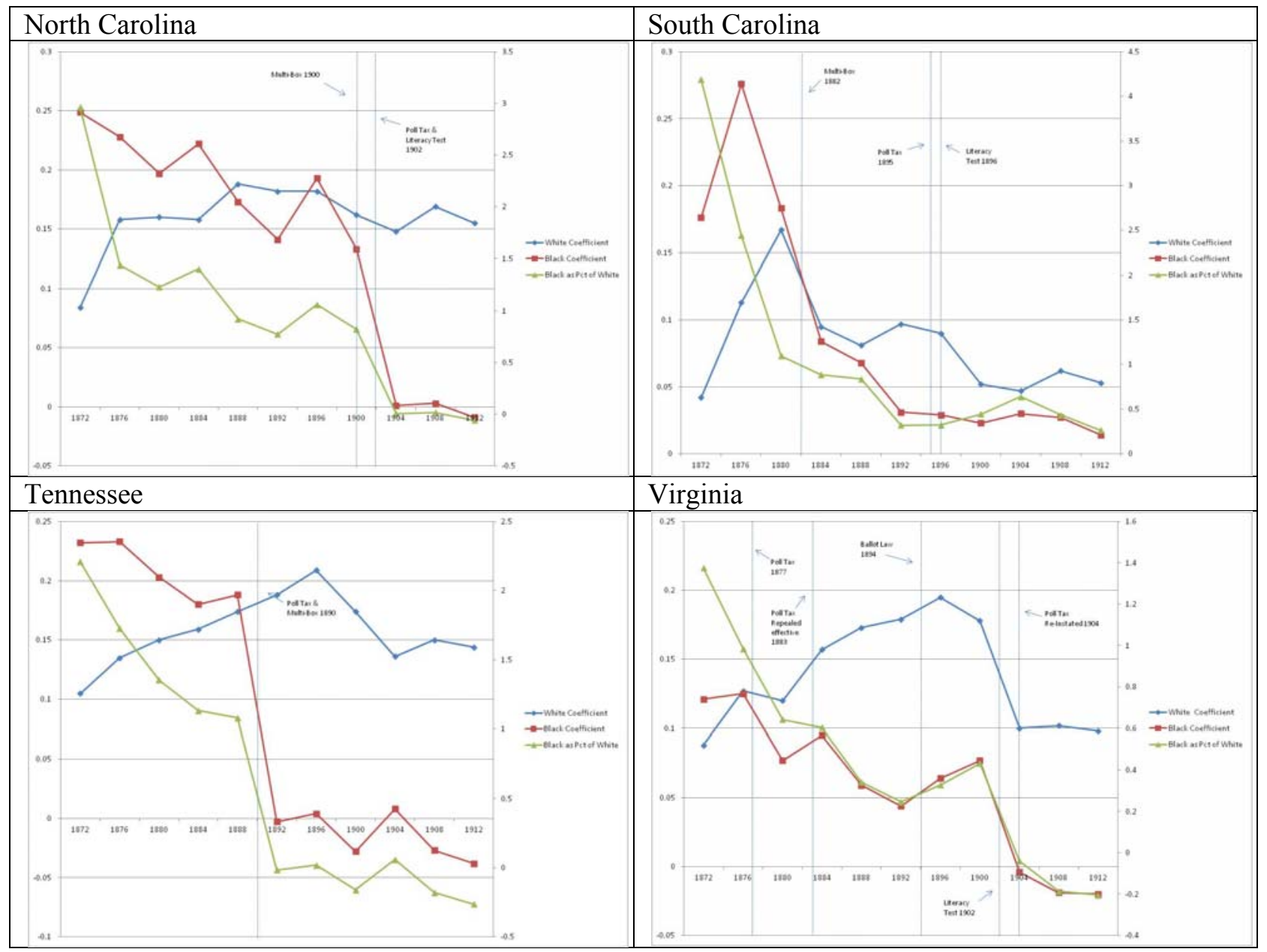

